University of Louisville

ThinkIR: The University of Louisville's Institutional Repository

Electronic Theses and Dissertations

$12-2007$

\title{
Analytical modeling of an autonomous vehicle storage/retrieval system.
}

Xiao Cai

University of Louisville

Follow this and additional works at: https://ir.library.louisville.edu/etd

\section{Recommended Citation}

Cai, Xiao, "Analytical modeling of an autonomous vehicle storage/retrieval system." (2007). Electronic Theses and Dissertations. Paper 196.

https://doi.org/10.18297/etd/196

This Master's Thesis is brought to you for free and open access by ThinkIR: The University of Louisville's Institutional Repository. It has been accepted for inclusion in Electronic Theses and Dissertations by an authorized administrator of ThinkIR: The University of Louisville's Institutional Repository. This title appears here courtesy of the author, who has retained all other copyrights. For more information, please contact thinkir@louisville.edu. 


\title{
ANALYTICAL MODELING OF AN AUTONOMOUS VEHICLE STORAGE/RETRIEVAL SYSTEM
}

\author{
By \\ Xialo Cai \\ B.A., Huazhong University of Science and Techology, 2005
}

\section{$\Lambda$ Thesis}

Sulnuitted to the Faculty of the Gradnate Solnool of the Cuiversity of Lonisville in Partial Fulfillment of the Recuirements for the degree of

\author{
Master of Science \\ Department, of Industrial Engincering \\ UNIVERSITY OF LOUISVILLE \\ Lonisville, Kentucky
}


(c) Copyright 2007 by Xiao Cai

All rights reserved 


\section{ANALYTICAL MODELING OF AN AUTONOMOUS VEHICLE STORAGE/RETRIEVAL SYSTEM}

$$
\text { By }
$$

$$
\text { Xiao Cai }
$$

B.A., Huazhong University of Science and Technology, 2005

A Thesis Approved on

November $30^{\text {th }}, 2007$

By the following Thesis Committee:

Thesis Director 


\title{
DEDICATION
}

This thesis is dedicated to my parents

\author{
Mr. Jiang Cali \\ and
}

Mrs. Moijuan Zhang

who have given me invaluable educational opportunitios. 


\section{ACKNOWLEDGMENT}

I would like to thank my major professor, Dr. Sunderesh S. Heragu. for his guidance and patience. I would also bike to expless ney thanks to me parentis. for 1. heir understanding and support during those tines when there was no light at the enct of anything. I would also like to thank Dr. Mahesh C. Gupta and Dr. John S. Usher who gave me many helpful suggestions. Also, many thanks to Dr. Gang Meng. who gave nue nany useful snggestions and guidance on the project. Finally, I womld like to thank my firends here and in Chinka. 


\section{ABSTRACT \\ ANALYTICAL MODELING OF AN AUTONOMOUS VEHICLE STORAGE/RETRIEVAL SYSTEMI \\ Xian Cai}

Novenulser 30 th, 2007

Automated vehicle storage/retrieval system (AVS/RS) technology is relatively now. It has boon applied successfully in several Europoan facilitios in 1990s. AVS/RS is a flexible system that is a viable alternative to antomated storage/retrieval ststems (AS/RS), a traditional material handling technology that has been in existence for more thin lifty years

There are very few papers in the literature that focus on the use of analytical models for estinating performance measures of AVS/RS. In this thesis, quening network theory is used to model an AVS/RS system to analyze its performance. The mantntacturing system performance andlyzer (MPA) is an open quening network (OQN) analyzer based on the paranctrie decomposition method. This thesis models the AVS/RS and uses MPA to analyze the performance of an AVS/RS configuration. A simulation model based on discrete cvents is also generated by Promodel to allow comparison of MPA results with those of simulation.

A wot interface for conceptralizing AVS/RS and AS/RS designt is presented in his thesis. This on-line tool provides a conveniont and fichelly interface between warhonse designers and the analytical nodel tool. Fon case stmdies of algorithens mubchded in the web interface are presented in the thesis. 


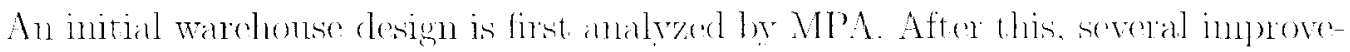
Inents of this initial design are exaluated. Experimental results are provided to show that the O(QN methodolegy can be applied effertively to analyo an AVS/RS when



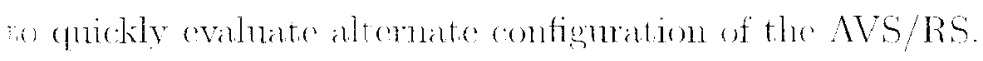

Adritionally, two more experiments are conducter fo compand WTA with another

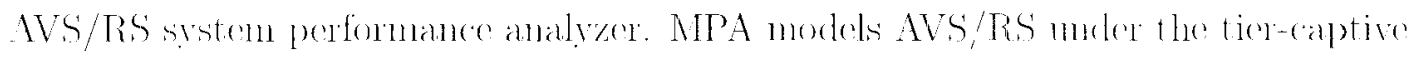

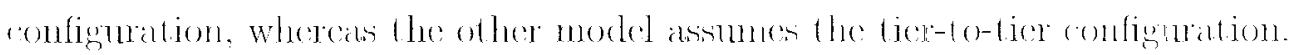


TABLE OF CONTENTS





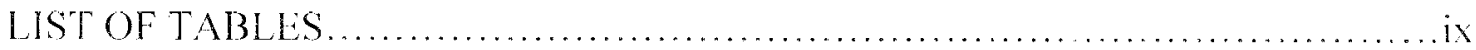



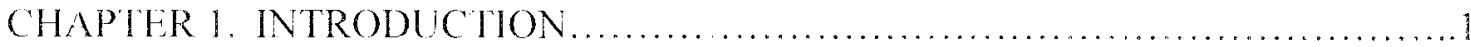

1.1. Autonomous Vehicle Storage/Retrieval Systems (AVS/RS),..............

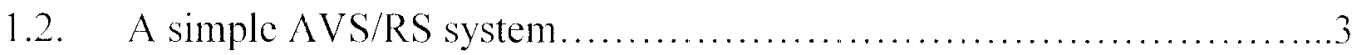

1.3. Background discussion .........................................................

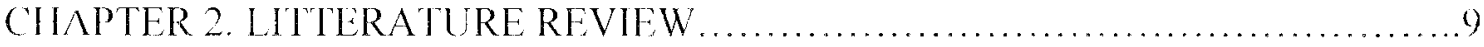

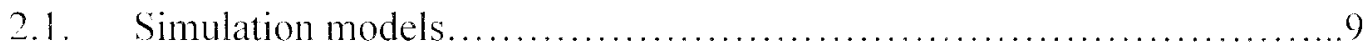

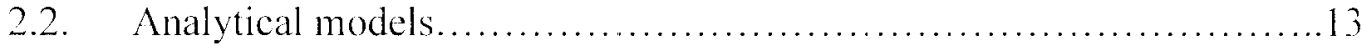

CHAPTER 3. MANUFACTURING PERFORMANCE ANALYZER...............16

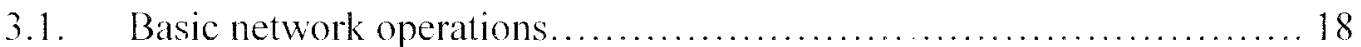

3.2. Estimating the first two moments of inter-arrival times............... 20

3.3. Estimating the first two moments of services times..................22

3.4. Network performance measures................................ 23

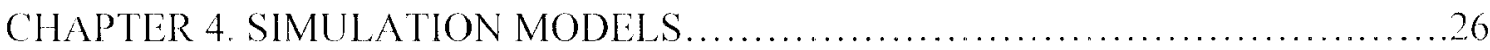



4.2. Model generation............................................. 26

(INPTER 5. APPLICATION OF MPA IN AVS/RS .......................... 30 
CHAPTRR 6. WEB INTERF ACE FOR TIHE CONCEPTUALIZATION OF $\triangle$ VS/RS AND AS RS..

6.1. Introduction of the web interface.................................. 34

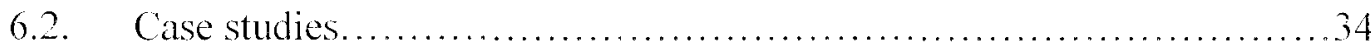

CHAPTER 7. EXPERIMENTS AND DISCUSSION $\ldots \ldots \ldots \ldots \ldots \ldots \ldots \ldots \ldots \ldots \ldots \ldots$

7.1. Comparison between MPA and simulation........................ 47

7.2. Comparison between MPA and the conceptualization tools........... 52

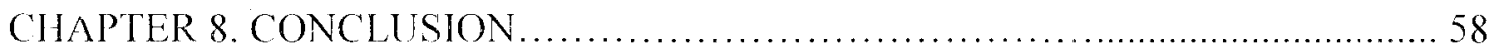

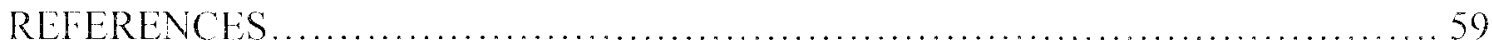

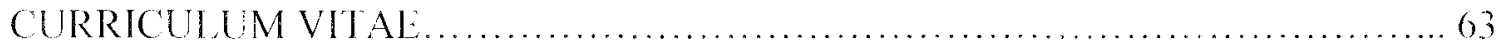




\section{LIST OF TABLES}

1.1 Location Propertics...................................... 27

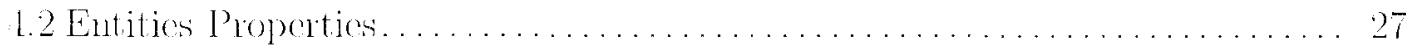

4.3 Processes Properties.......................................... 27

5.1 Server paraneters . . . . . . . . . . . . . . . . . . . . . .

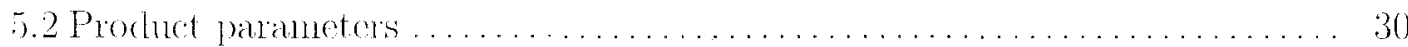

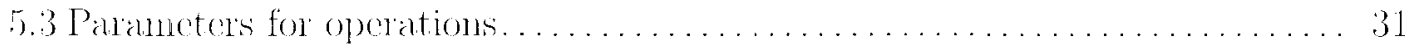

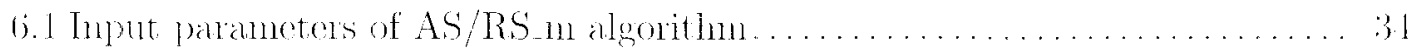

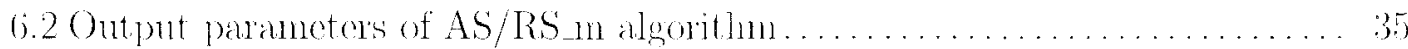

6.3 A study ase using the AS/RS_m algorithm. . . . . . . . . . . . . . 35

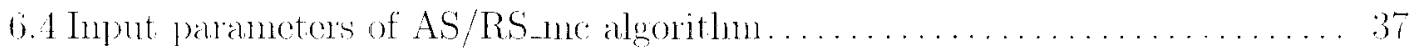

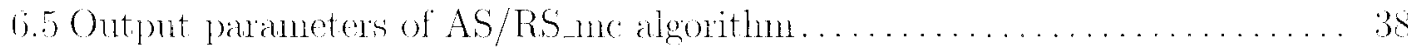



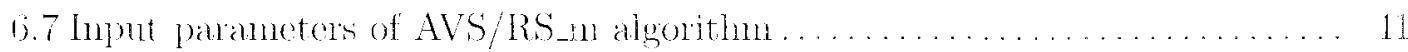

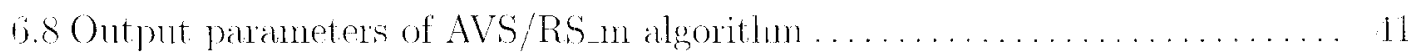

$6.9 \mathrm{~A}$ study rase of using the AVS/RS_m algorithn. . . . . . . . . . . . . 12

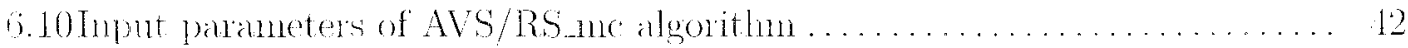

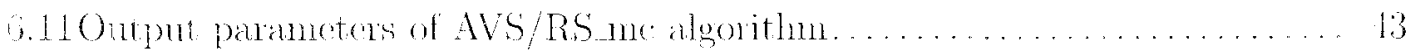

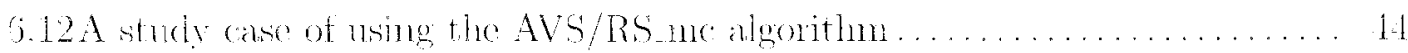




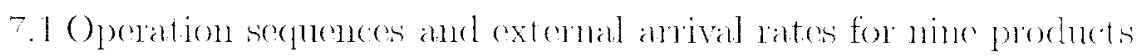

7.2 Prochuct operation times

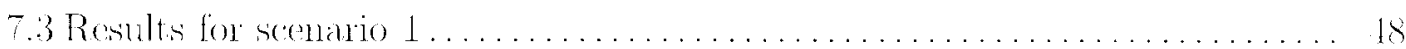

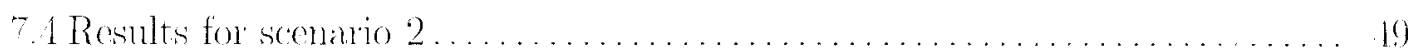



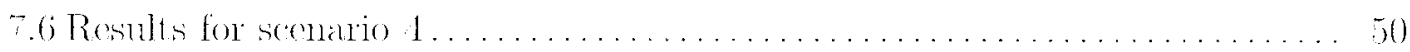

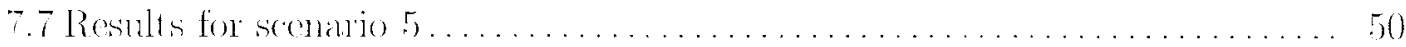

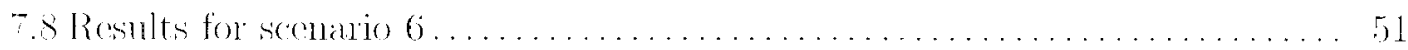

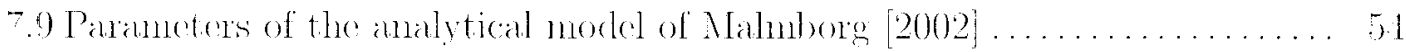

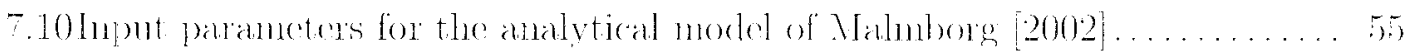

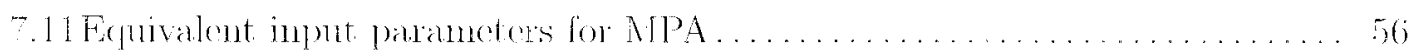

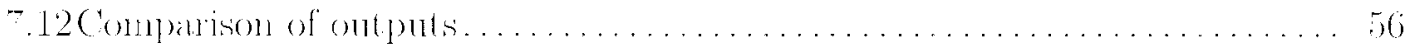

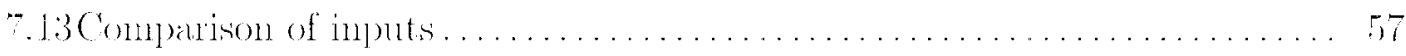




\section{LIST OF FIGURES}

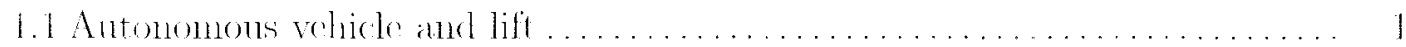



1.3 Representation of an AVS/RS with then tios . . . . . . . . . . . . .

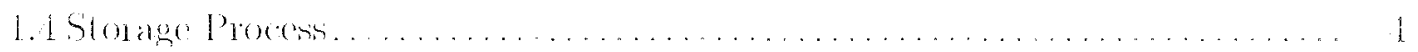

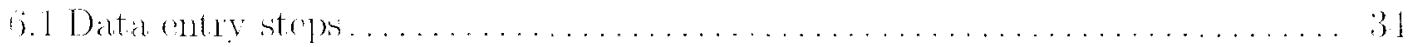

ij.2 Input parancters page of $A S / R S$ m algorithm $\ldots \ldots \ldots \ldots \ldots \ldots \ldots \ldots \ldots$





5.5 ()utput paraneters page of AS/RS nur algorithm . . . . . . . . . . . 10

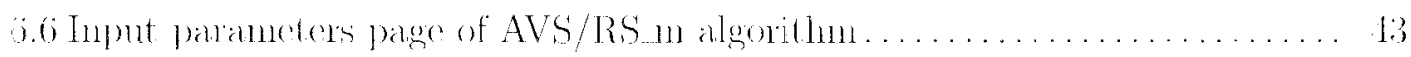

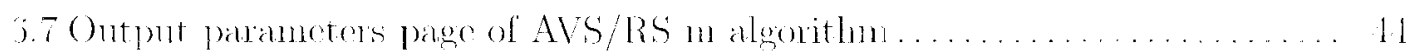



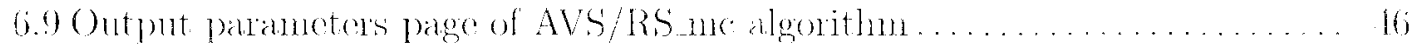

$7.1 L_{q}$ and utilization of servels in sermato $1 \ldots \ldots \ldots \ldots \ldots \ldots \ldots \ldots \ldots \ldots$

$72 L_{1,}$ and utilization of servers in sematio $2 \ldots \ldots \ldots \ldots \ldots \ldots \ldots \ldots \ldots \ldots$

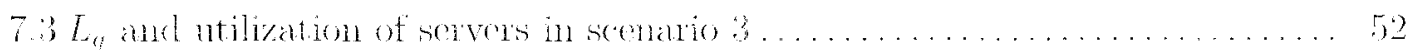

$7.1 L_{q}$ and utilization of serves in serentio $1 \ldots \ldots \ldots \ldots \ldots \ldots \ldots \ldots \ldots \ldots$

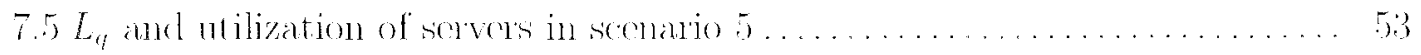


$7.6 L_{i q}$ and utilization of servers in secmasto 6 
(IIAPTER ।

\section{INTRODUCTION}

\subsection{Autonomous Vehicle Storagc/Retricval Systems (AVS/RS)}

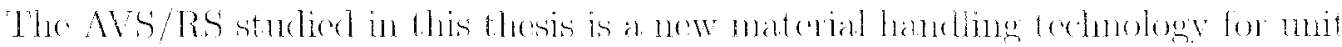

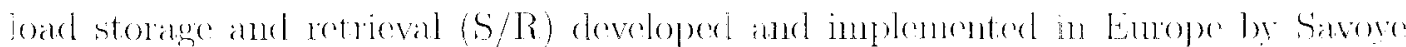
Trethologies.

\subsubsection{Components of AVS/RS}

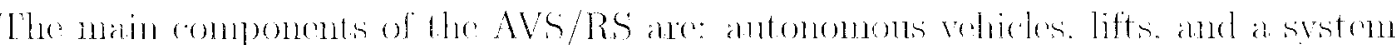
of tails that fareditale movement of the vehiches. These ane illustrited in Figure 1.1.
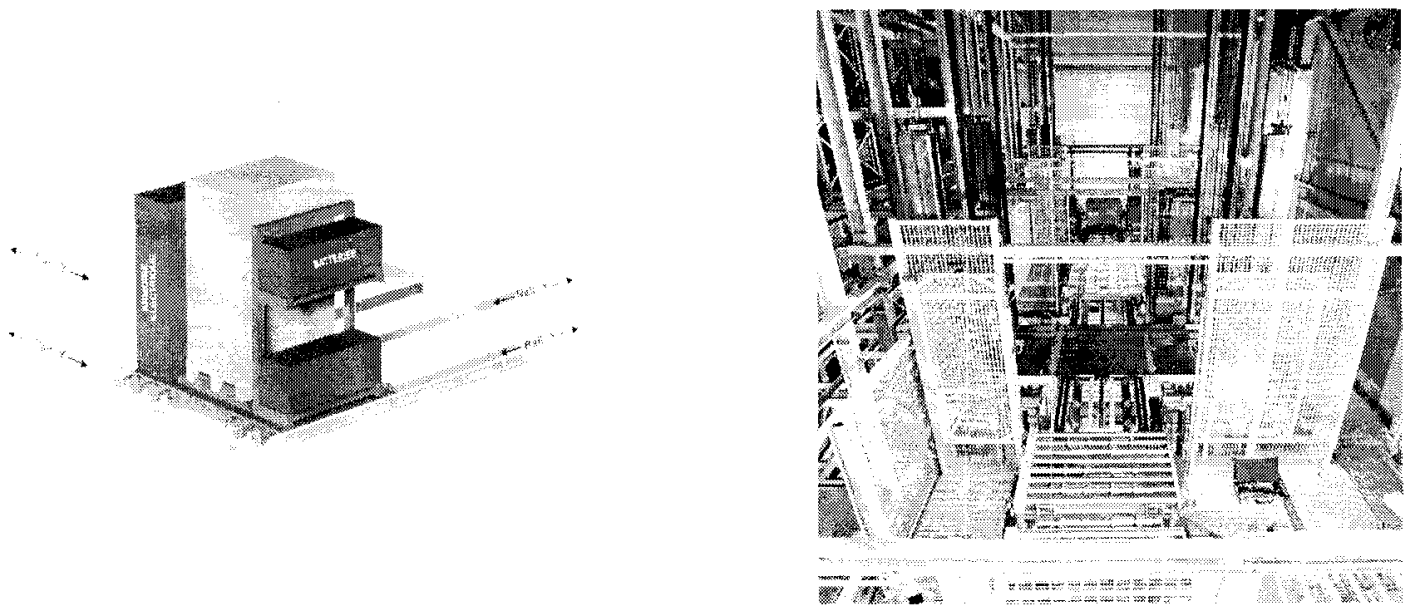

Figme 1.1. Autonomons veluele and lit

\subsubsection{AVS/RS Configurations}


$m$ 
- AVS/RS with her-to-tion vellicles

- AVS/RS with lier-captive velicles

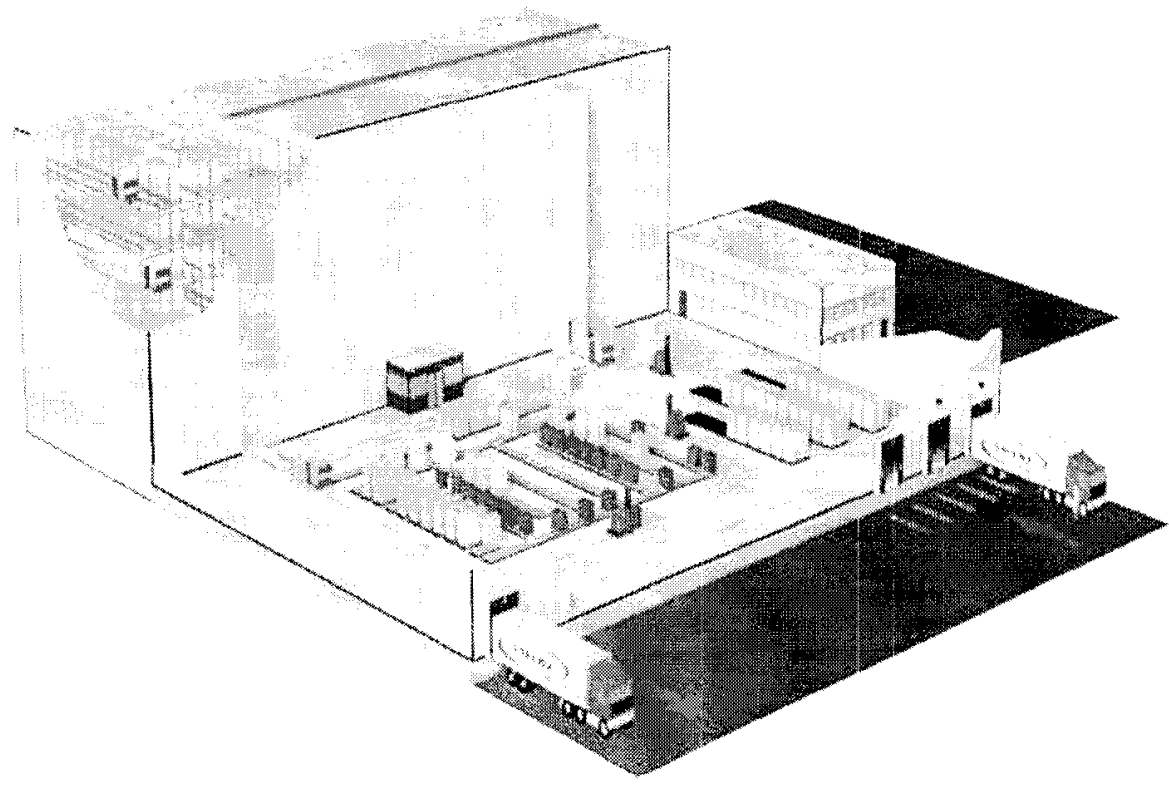

Figure 1.2. A typical AVS/RS

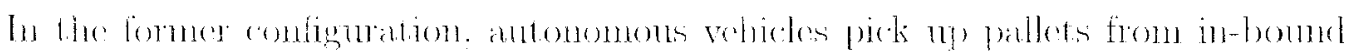

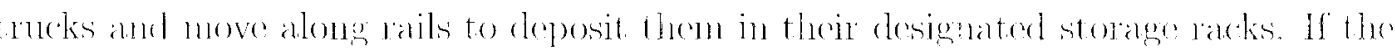

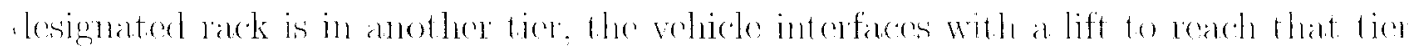

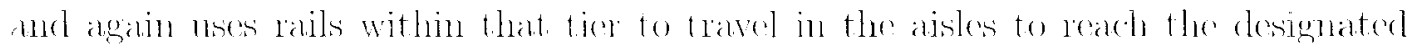
itorage spare. The operations are reversed for anetrievel transaretion.

AVS/RS with tier-aptive veholes operates differently when the desighated rack

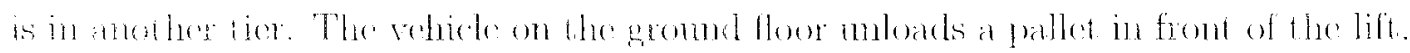

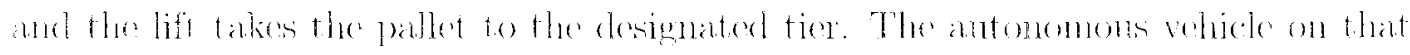






\subsection{A simple AVS/RS system}

\subsubsection{Description of the simple system}

A simple MVS/RS with tion-captive vehicles is presented in Figure L.3. This svitem

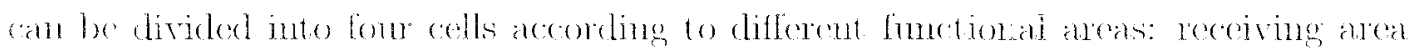
(Coll 1). lift bank (Coll 2), shipping area (Coll 3) and storage anca (Coll 1).

Pallets containing different types of products arrive at the receiving ancer ready to be stored at their designated storage spaces by the AVS/RS. Pallet arrival rates usually are described by a probability distribution of the number of mavalis in an interval of tinne. Ther are taken by available antonomons voliteles in the receiving anca (Cell 1) to lift bank (Coll 2). If no vehiche is avalabule pallets wait in a clucue at the receiving buffer on the gromed level. Ther are transported by veliedes on the gromed level to the lift bank and deposited in front of the lift bank (Cell 2). If no lift is available, pallets wait in a quene. Once a lift becomes available, the waiting pallet is taken to the designated tier (Cell 4). An autonomons whick takes the pallet to the designated storage position detemined by a storage policy. If there in no veluche avalable, the pallet has to wait in the buffer area in that tier. Figure 1.4 illustrates the storage process in this system. The retrieval process is a reverse order of these wonts.

\subsubsection{Queuing network theory}

Based on the $S / R$ procesis of this simple AVS/RS. it is reasomable to treat this system



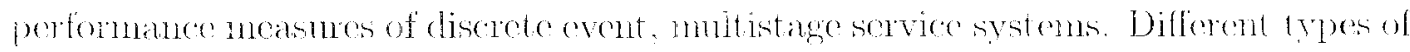
customers miving from the ont sicle work ented the system to complete several stagen of service, and then leave the system. The main components of a cuening notwouk 


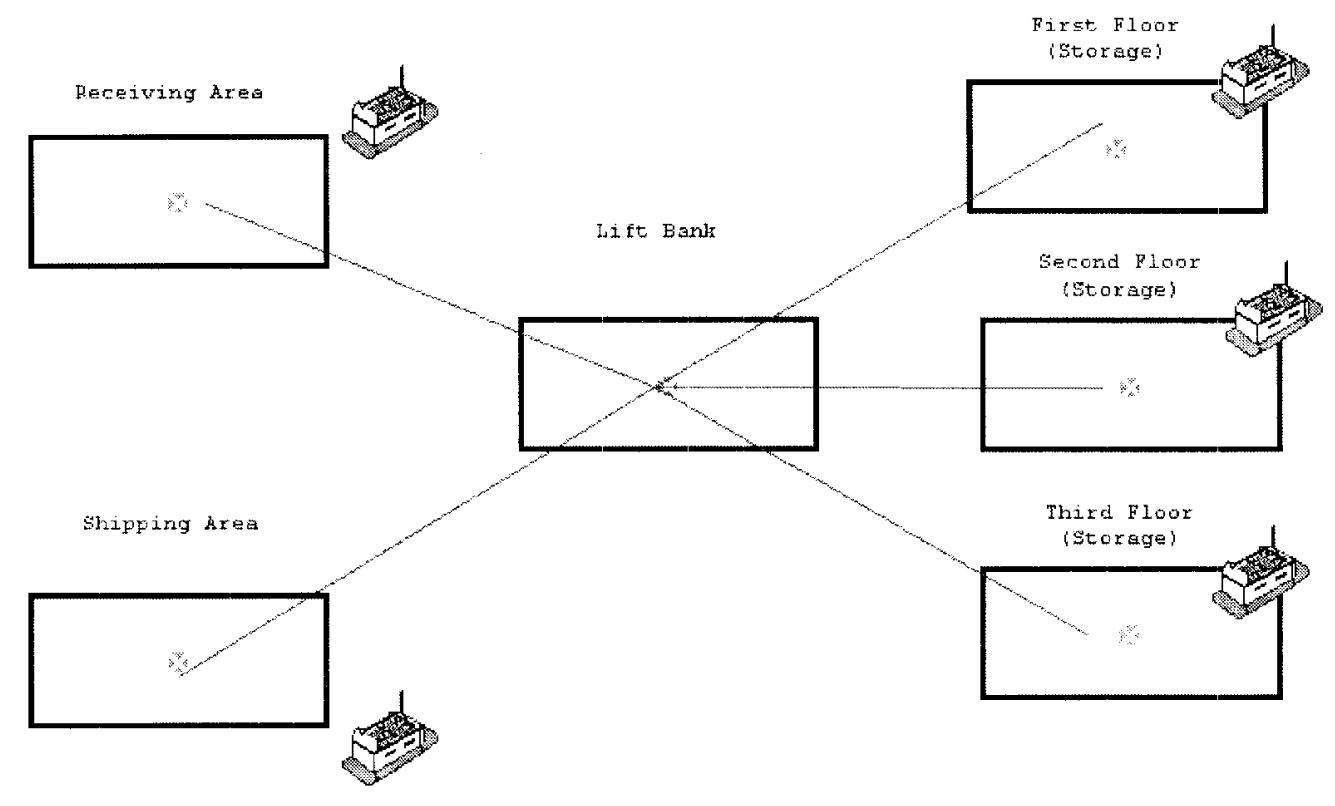

Figure 1.3. Ropresentation of and AVS/RS with then tions

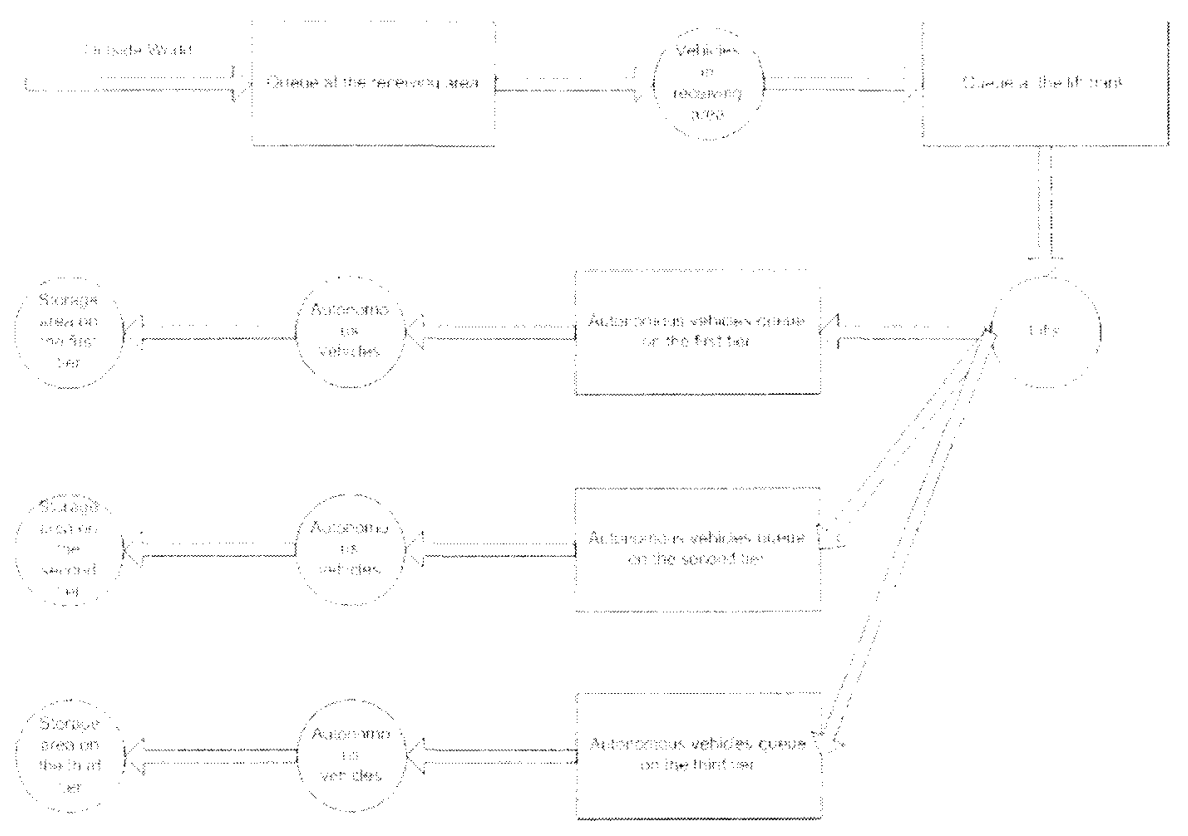

Figure 1.1. Stomage Procests

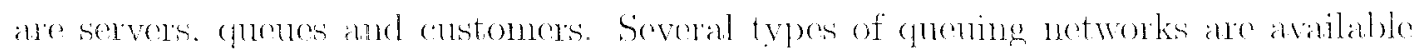


in the literature - Closed Quening Network (CON), Open Qmening Network (OON), and Seni-Open Quening Network (SOQN).

The CQN has a population eonstraint and implicitly assmes there ane infinite rustomers just ontside the network. The population constraint is enfored by paining

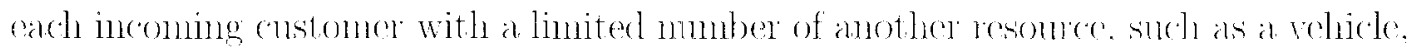
which stawe with the contomer until the last stage of servien is completed. When Whe custoner leaves the system, the rewomen retums to the beginning of the network reakly to be paired with a new anstomer. The number of resoneces is finte then anforcing the population constraint in a CQN.

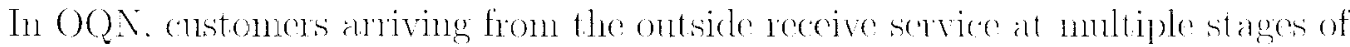
servers, and then depart from the system. The O(2N inplicitly assunes there is an

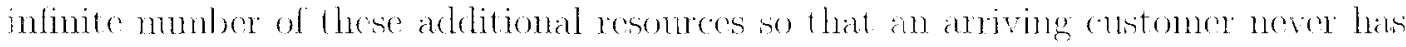
no wait in the exterial quene.

SOCN. on the other hand, models the nome rolistic semaro, where a customer maty have to wait for the resoure or viec-versal and provides hetter estimates of total ryele tine and work-in-poress (WIP) inventory (Srinivasun and Heragu [2007]).

To alpply (quening network theory to an AVS/RS, the pablets are treated as cusromers, and the antonomons velickes and lifts are modeled as servers in the chuening atwork. Beranse volicies and lifts are servers. and served times ale travel tines of hese devices, pallets need no resonce to "travel" between these servers. As a result, the OQN is sutable for this $\mathrm{NVS} / \mathrm{RS}$.

There are many OQN analyzers in the literature, such as the well-known Qnening Network Analyzer (QNA), and Mamufactuning Perfomnanes Analyzer (MPA). MPA

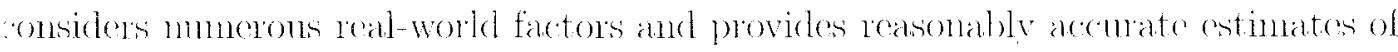
profomance moanmes. 


\subsection{Background discussion}

In the previons section, it is mentioned that AVS/RS' is an anternative to AS/RS. In this serdion, a companison between AVS/RS and AS/RS in presented to moliente arkantages of the AVS/RS.

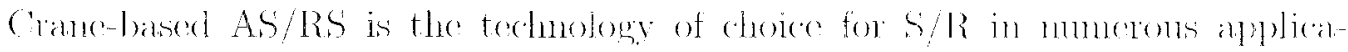

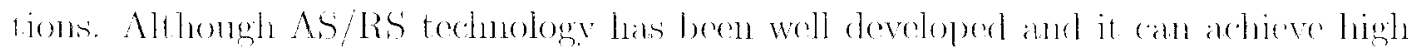



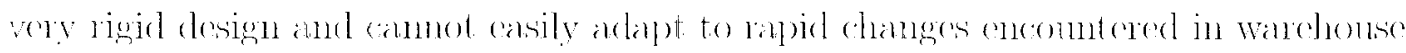

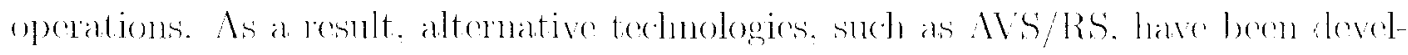
operl and inplemented. The AVS/RS hias many alvantages when eompared with an As/Rs. These include flexibility and modularizalient and are presented next.

\subsubsection{Flexibility}



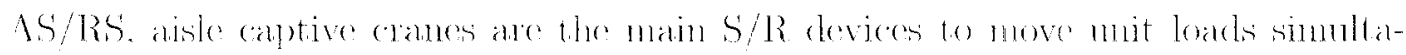

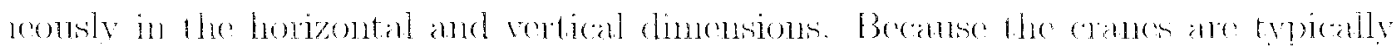

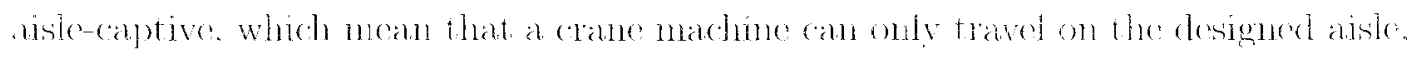

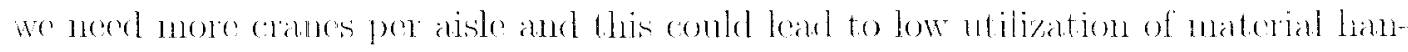



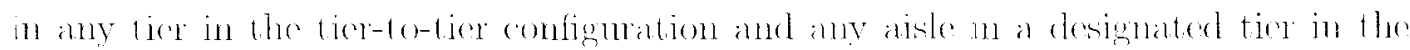



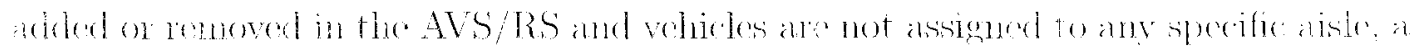


upplication recpunenuents 


\subsubsection{Modularization}

The second advantage of AVS/RS is modulanization. Because cranes complete all

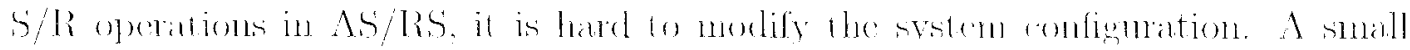

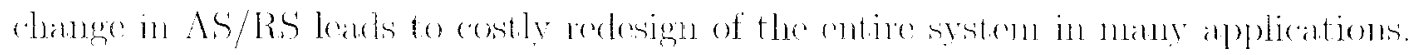

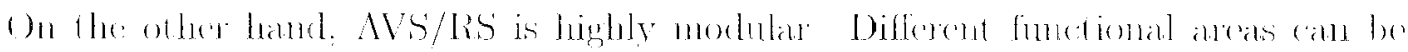

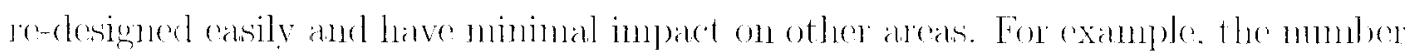

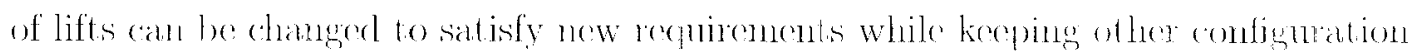

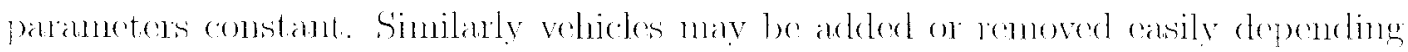
iponthe themghput requirenents.

\subsubsection{Dispatching transactions rules}

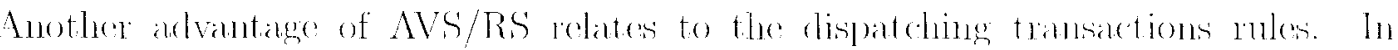



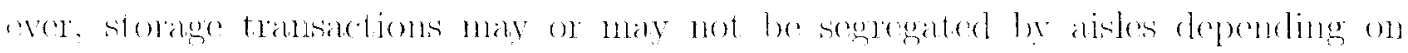

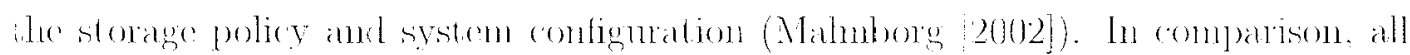



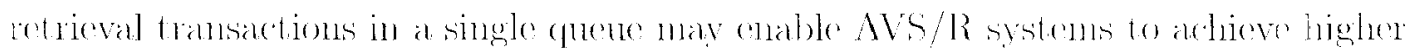

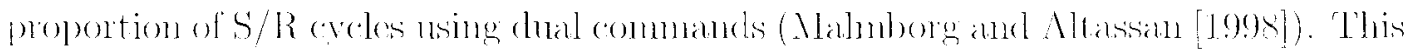

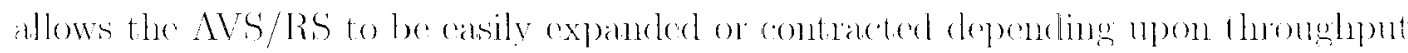

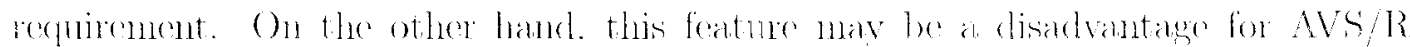

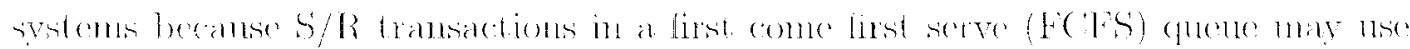

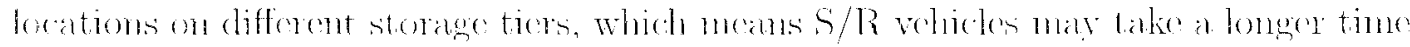
to complete the $S / R$ transactions. 


\subsubsection{Main contributions}

The main antributions of this thesin ane:

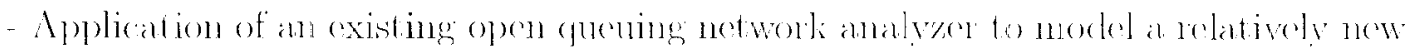
material handling tedoungloge.

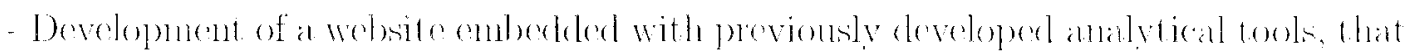
allow a designer 10 compane alternate conlignations of AS/RS and AVS/RS

\subsubsection{Thesis Organization}

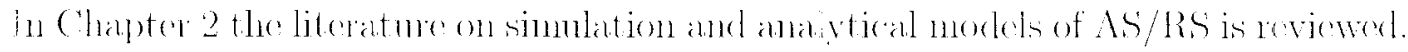

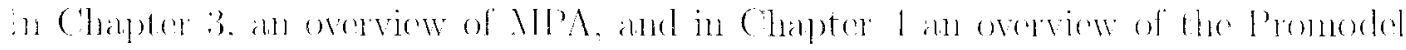

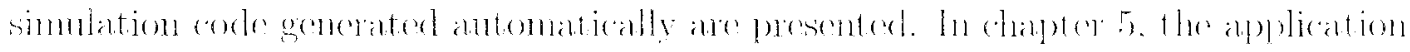

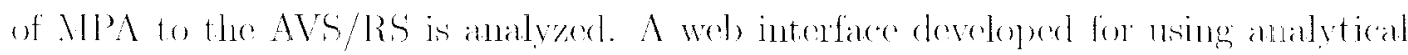

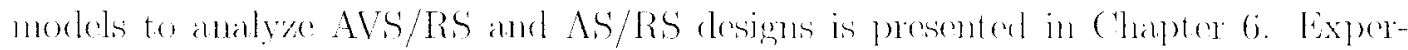
jumental results and a comparison of $\mathrm{MP} \Lambda$ is performaner with that of a simmlation model ane presented in Chapter 7 along with a companison betwen Ml'A and another

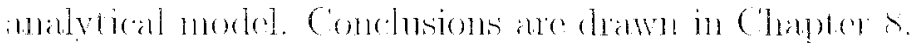


CHAPTER 2

\section{LITERATURE REVIEW}



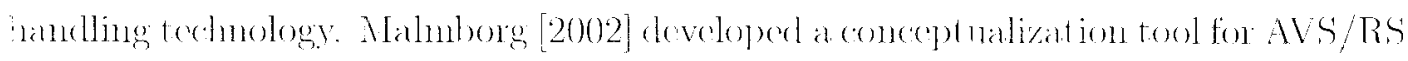

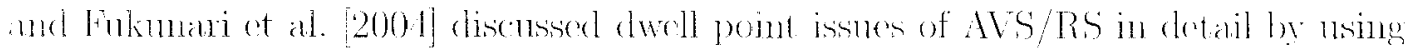
1 decision-tien analysits.

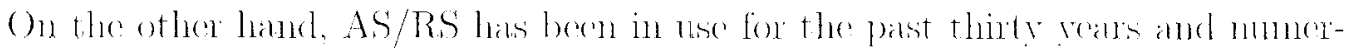
mes morleds have been developed. Varions sinulation morkels of AS/RS exist in the

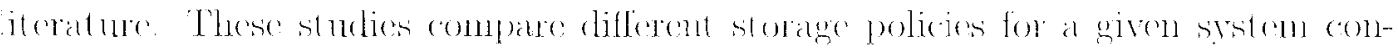

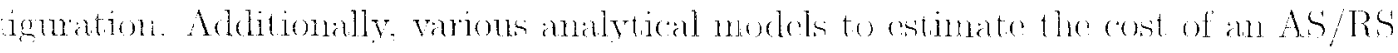

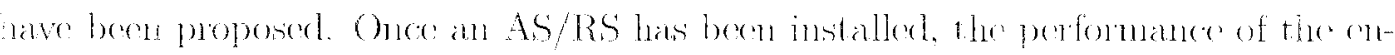
rine system depends on contrel methods applied to the system. The eontrol nuthodis anclude storage method, oreler seguencing, and dwell points of $S / R$ maxhines.

\subsection{Simulation models}

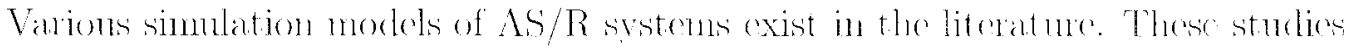

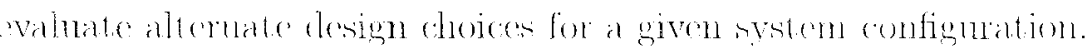

\subsubsection{Sizing problem}

The sizing problen of warehouse design is a combined problem. Which is cansed not

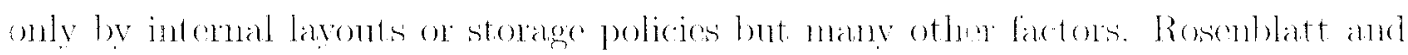
Roll [1981] presented a combined approath of optimization tedmignes to denemine

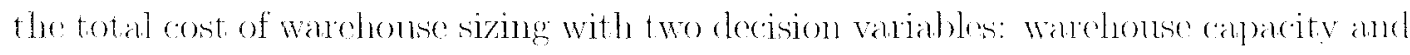

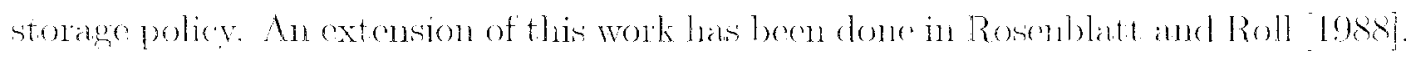


A simulation moded was developed to medsme the relationship between warehomse sime and varions pertinent parameters. The stochlistic nature of the demand and replenishment gequires us to deternine the warehoube capareity by the desired servien








Roll [1988] pointed ont that a warehonse with an NCR compareity will provide only a

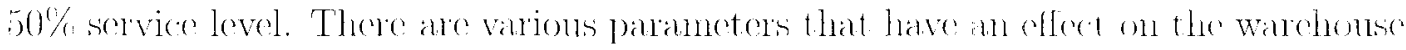
size for a given servier level. These were studiod using a simulation model. Multi-aisle S/R machine system (MASS) was studied by Hwang and ho [1988 to reduce the

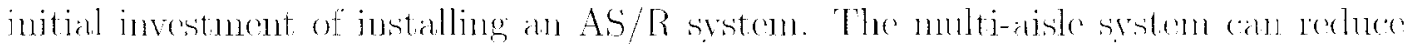
the installation cost drandatically to half the cost of single-aisle $S / R$ manchine sistem as lomg as the s/R demands are matively low.

Choi and Shin [1997] described a paint borly stomge (PBS) at an antomolibe

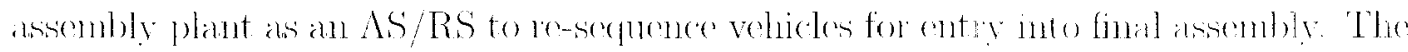
extension work of the application of $\Lambda S / R S$ in antonotive andenbly secpences has



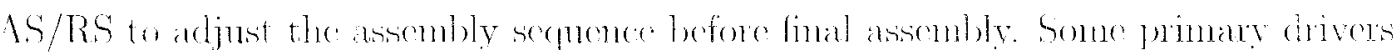



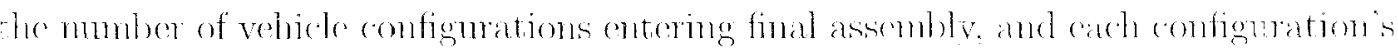
penetration. Lnunan [2003] presented an analytical moded for siring this post-paint AS/RS by andidering these nentioned factors. 


\subsubsection{Deadlock problem}

A large number of studies have discussed classical operational problems such ats dwell points, expected cycle-time models and optimizing transporter operations (Borg and Gademan $[2000])$. However, thene ane relatively very fow papers in the literature dealing with operational controlle tasks such as avoiding veliede deatlocks in the?

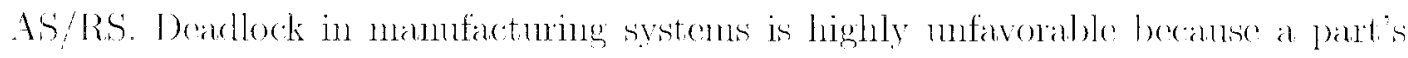
ancess to resourees is held up by other parts. One method of andlock resolution is to abort one or nore parts involved in the deadlock and relcasing resonnes to other parts (Fanti ot al. [1997]). The apploades to anderess deadlocks are provention

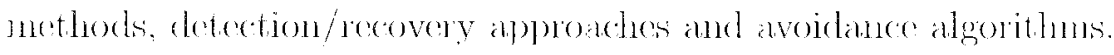

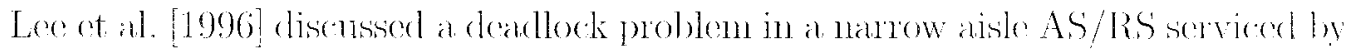

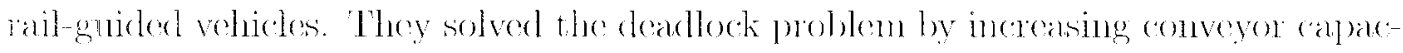
ity in the simnlation model, which is a deadlock detection/recovery (DDR) mothod. However, the solution of deadlock problems had not becn formally describod. In order 10 chatraterize the deatlock in the AS/RS correctly a model should be establisherl.


As/RS transunt system by ning colored timed Petri nets (CTPNs). The CTPN an


Although the CTPN is resomerendented and suitable to me in operational level, it is 100 complex for deared erizing the deadlock and defining efliciency resolntion policies for AS/R systems. Dotoli and Fanti [2007] presented their extended work of deadlock detection and avoidanee strategies in $\mathrm{AS} / \mathrm{R}$ systems. The AS/RS is modeled as a



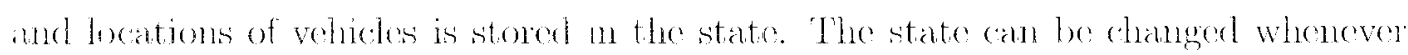
and ovent oceous. This dharacterization can be used in the analysis of deaflocks in the 4S/TSS. 
Dotoli et al. [2004] compared two different real-time deadlock solution strategies for the AS/RS: a deallock avoidinee strategy and a deadock detection/recovery stratcegy. The deadlock avoidance strategy was proposed by Fanti [2002] to guarantee an efficiont system performanec using a DEDS and digraph tools. The DDR strategy Was proposed by Lee et al. [1996] to solve the deadlock problem loy utilizing buffers 1.0 store readlocked jobs.

\subsubsection{Travel-time models}

The service time for a transaction includes both $\mathrm{S} / \mathrm{R}$ machine travel time and picknp/deposit time. The pickup/deposit time is assumed to be deterninistic due to the nature of the $S / R$ machine. The travel time is variable and is thus useful in measuing inmortant performance neasures of AS/RS, for example throughput tinnes. For single shuttle AS/RS, S/R mathines can perform up to one storage and one retrieval operation as a dual command cycle (DO). However. in multi-shuttle AS/RS with two mit loaks, the $S / R$ machine (an perform up to two $S / R$ operations in a "ycle as a quadruple command cycle (QC). Potrc et al. [2004] presented a simulation model of multi-shuttle AS/RS by using, a new houristic strategy instean of FCFS strategy in single-shnuttle AS/RS. This smmlation model indicates that multi-shuttle AS/RS has large improvenents in travel time when compared with single-shuttle AS/RS. Hu et al. [2005] presented a contimous travel-time noded for a new type of AS/RS, split-platform AS/RS (SP-AS/RS). By introducing a new S/R nnechamism for iandling extra heavy loads efficiently, the SP-AS/RS shows improved S/R machine mavel-times. 


\subsection{Analytical models}

Additionally, various analytical models to estimate the cost of an AS/RS have becn proposod. Once an AS/RS is installed, the performance of the entire system depends on control methods applied on the system. The control methods inchude storage nethod, order sequencing, and dwell points of S/R machines. Rescarch in the area of dwell points and expected travel-time models for $S / R$ machines are reviewed in this section.

\subsubsection{Dwell points models}

The first anca relates to dwell points. Some simple rule-of-thumb policies have been studied by Bozer and White [1984]. These strategies are easy to understand and implement. Int they are static and cannot respond to changes in the S/R transactions in an AS/RS from period to period. Eghelu [1991] developed a dynamic optinal location strategy based on mathenatical programming inchuding two separated sub models to minimize the scrvice response time. One sub model is to minimize the maximm S/R machine response tine while the other solves the minimization of the rexpected response time. Hwang and Lim [1993] extended the Egbelu [1991] study by transferring one sub model to a single-facility location problenn and devoloped an efficient algorithn to generate an optimal dwell point of $S / R$ maxhines in $A S / R S$. Sereral dwell point specification strategies for $S / R$ machines have been studied by Egbolu and Wu [1993] based on the simple rule-of-thumb policies by Bozer and White 1984 and dynanic strategies based on linear program developed by Egbeh [1991]. Eghedu and Wu [1993] conducted a performance comparison by using average order mumaromed time as the basis for comparison. The choice of the dwell point lats a significant impart on expected response time of AS/RS. Peters et al. [1996] developerd an analytical model for the determination of the optinal dwell point location for an 
S/R machine. This morlel provides a closed form solution for the dwell point location problem molder a variety of system configurations. Poters ot al. [1996] developed a losed form solution for square-in-time (SIT) racks. However, racks are not necessarily SIT, which means study of non-square-in-time (NSIT) and uniformly distributed racks ure more valuable. Park [2001] developed a closed form solution for the optimal dwell point of NSIT racks detemined by the probability of the next transaction demand ype - storage or rotrieval. In addition, varions retum pathe to dwell points are also exanined in this paper.

\subsubsection{Expected travel-time models}

Another study area is the expected travel-time of $S / R$ machines in AS/RS. Three storage assignment rules have been compared hased on expected travel-time of $S / R$ machines by Hansman et al. 1976). They pointed out that there is a significant redurtion in crance travel time by using dedicated storage policy such as full trunover-based assignment rathes: than randomized storage policy. Graves et al. [1977] extended the work rlone by Hansman et al. [1976] to compare the operating perfomance of several storage assignment policies by using both continuous and cliscrete evaluation modcls. Each rule is compared on the basis of expected travel-time of $S / R$ machines. Bozer and White [1984] developed travel-time models for single or dual command aycles. They compared the expected travel-tine of an AS/RS cranc for these two (yales. Travel tirnes under different storage assignments have ben investigated by Won et al. [2001]. They considered varions travel spects with known arceleration and dereleration mates. A computerized algorithm developed by Mansuri [1997] investigated dedicated storage allocation altenatives for an AS/RS based on cycle tine of the S/R

rane. Ashayori of al. [2002] presented an exact. geometry-based analytical model to wompute the expected cycle travel-time for an $\mathrm{S} / \mathrm{R}$ machine with single-command, 
dual-command, or both. The raxk can be either SIT or NSIT and no fixed layout shape is assunced in this model. This approach can make the AS/RS more apperang for use in integrated smpply chain systems. Sari et al. [2007] presented closed-form travel-time expressions for flow-rack AS/RS based on a continuous a pproach and conpared them with simulation to demonstrate that this analyical nodel can estinnate performance measures by requiring less computing time than simulation.

\subsubsection{Dynamic control policies}

Proper selection of dynamic control policies allows us to maximize the system throughput. Lin and Wang [1995] presented an application of stochastic Petri nets (SPNs) 10 describe the behavior of $A S / R S$ and evaluate the performance of different control policios of such systems. Tho SPN is a graph-based tool that can build a system at different levels. This property of SPN can divide the whole system into several sub systems and model then separatcly, which nakes it is easy to romodel changes in sivstem configurations dhange. Dotoli and Fanti [2005] developed a colored Petri net (CPN) to investigate the performanee of AS/RS from a control perspective. CPN is a well-known dialect of high-level SPNs that can be implenented in work flow analysis. This allows us to model a resource-oriented model suitable for real-time control. A jorformance analysis for multiple aisle AS/RS by nsing SPNs is presented by Benamar et al. [2003]. Tinned Petri nets (TPNs) extended from CPNs with time concepts is applied to model the AS/RS and evaluate systen performance. 


\section{CHAPTER 3}

\section{MANUFACTURING PERFORMANCE ANALYZER}

In the introduction we mentioned oON can be msed to moded the AVS/RS. 'Illewe are many medhods developed to analyze OQN. Exact solution is postible for metworks with exponential inter-arrival and service time distributions. However, extermal araval procenses of complex quening networks need not be Poissone and the serviec inne distributions need not be exponential. In order to solve more general fuending

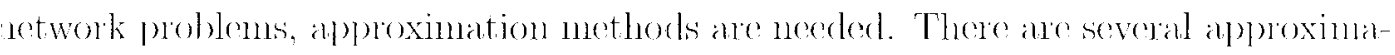

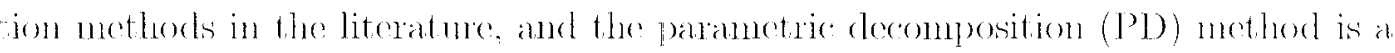
x)pular methorl.

The main idea of P'D is to decompose a complex (nuening network into several isoanted (quenes or subsystems (Kinehn [1979]). Koy points of PD indude lwo principles. 'The first one is apporoximation of all non-renewal processes by stationary lenewal prorestes. A renewal process means cery time an event oceme the process renews itself

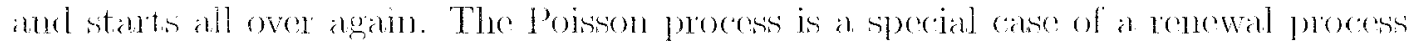
where time between ocenteneses is expenentially distributed. Typically, a complex st tochast ic process has one or more embeded renewal processes, which allows the preress to be decomposed into smaller independent systems. Fon example, Markovian networks can be decomposed into subsystens exantly, while general networtis only "an be decomposed approximately. Another important princigle is consideration of i.te first two moments - mean value and seplated coefficient of variation (SCV) of

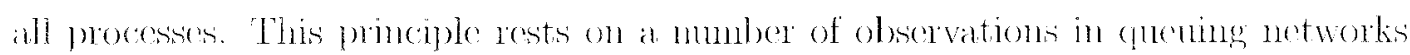


where moan values of performatere measures are mainly influenced by the mean and SCV of a ranclon variable.

QNA developed by Whitt [1983] is a software parkage for O(2N in communication systems, but it was modified to model discrete parts manufacturing systems. The approximation method in ONA acomposes the quening network into several stochastically independent $G I / G / m$ cuenes. A $C I / G / m$ gunene indicates that the arrival process of the (queue with $m$ multiple servers is a renewal poress with general distribution ( $G T)$, and the distribution of service time is also general (G). QNA uses

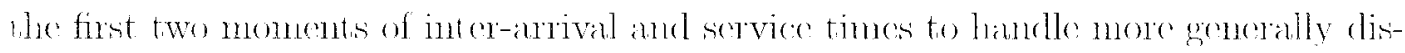
milmed o(gNs. One the first two moments of the inter-arrival time of each customere type into the network and its routing are given, QNA calculates the first two monents



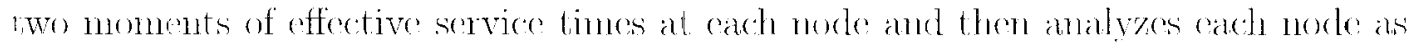

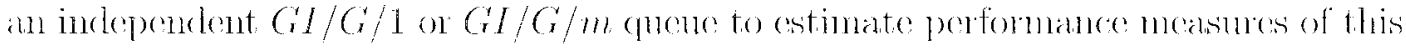
morke. Finally, performance measures of the cutire quening network are estimated by synthesizing performande measures of these independent $G / / 6 / 1$ or $G / / G / m$ quenes 1. Whitt [198:3]).

MPA, an extention of QNA, and described in Meng and Heragn [2004], is an analytical model sperifically designed to evaluate the performance of a manulareturing system. The analytical noolel of MPA in the context of a manufacturing system is introduced by briefty recapping the two systems of linear equations used to calculate he first two monents of inter-arrival and serviee times.

The notations ned in MPA are listed here:

$$
\begin{aligned}
& n-\text { mumber of servers } \\
& p=\text { mumber of product types } \\
& i=\text { product type index } i=1,2, \ldots, p
\end{aligned}
$$


$j, k=$ server node index $j, k=1,2, \ldots, n$

1 - operation index, $l=1,2, \ldots, o^{i}$

$m_{j}=$ mumber of manclines at morle $j$

$\lambda_{\text {h }}=$ rate at which a product leaving node j goes to node $k$

$\lambda_{j k}^{\prime}=$ mate at which a product anriving at node $k$ comes from node $j$

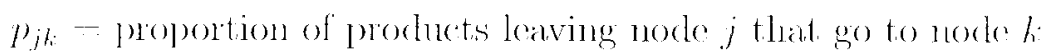

$p_{j k}^{\prime}=$ proportion of products anriving at node th that come from nok jo

$a_{a j}^{2}=S C V$ of inter-amival time for two consecentive meivals into node $j$

$\tau_{s, j}$ mean service time on makdines at node $j$

$r^{2}=S C V$ of service time on machines at node $y$

$b_{k, 1}^{i}=$ operational batch size of lth operation of product i on mardines at norle $h$

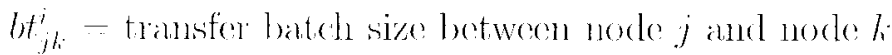

$\gamma_{j k}^{h \prime}-$ relative bated size of the operation of product i performed on machines at node if to the bateh size of $(7+1)$ the operation of that product on manchines at nocke:

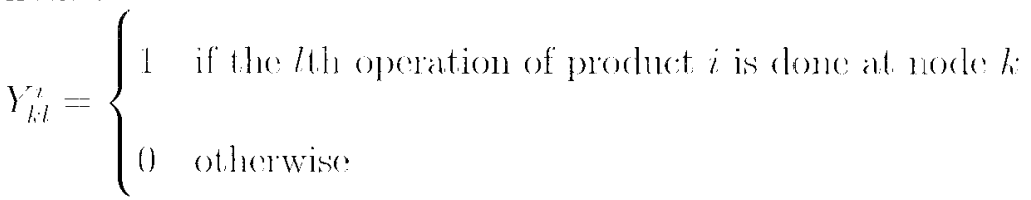



\subsection{Basic network operations}

Whit [1983] pointed out that an O(2) combines several basic network operations no matter how complex the network is. These network operations are eleparture, split and superposition. Feffects of these operantions are discussed next.

1) Depanture operation 


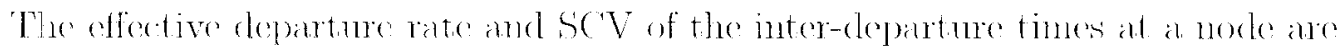

$$
\begin{gathered}
\lambda_{a}=\lambda_{a} \\
r_{d=1}^{2}=1+\left(1-\rho^{2}\right)\left(r^{2}-1\right)+\frac{\rho^{2}}{\sqrt{m}}\left(r^{2}-1\right)
\end{gathered}
$$

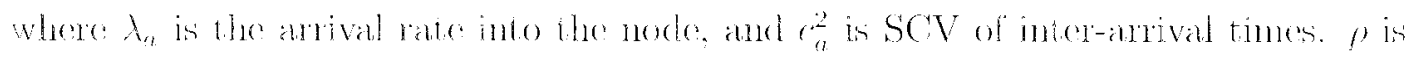
the tratfie interisty or ntilization at the nocke.

$$
p=\lambda_{n} \tau_{s} / m
$$

2) Split. operation

The aggregate product is split into subaggregate producte via the split operation.

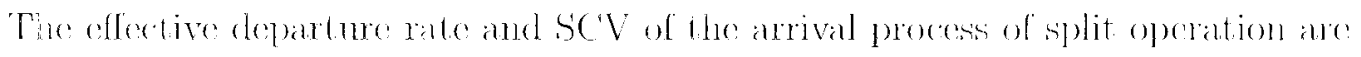

$$
\begin{gathered}
\lambda_{i}-p_{i} \lambda_{a} \\
c_{i}^{2}-p_{i} r_{a}^{2}+1-p_{i}
\end{gathered}
$$

3) Superposition operation


linst two moments of the arrival process of sulperposition are

$$
\begin{gathered}
\lambda_{n}-\sum_{i} \lambda_{i} \\
c_{a=}^{\prime \prime}=\omega \sum_{i}\left(\frac{\lambda_{i}}{\sum_{\lambda} \lambda_{k}}\right) r_{i}^{2}+1-\omega
\end{gathered}
$$

The woighting function is

$$
\omega-\left[1+2.1(1-\cdots)^{i+4}\right]^{1}
$$


where

$$
\nu=\left[\sum_{i}\left(\lambda_{i} / \sum_{k} \lambda_{k}\right)^{2}\right]^{-1}
$$

\subsection{Estimating the first two moments of inter-arrival times}

As mentioned previonsly, the first two moments of effective inter-arival times ane Dhtahed by solving two sytens of hinear equations. which synthesize the effects of Hese three basic network operations on the first and second monents of the intermival times.

The first system of linear equations alculates the effective anival rate into ead sode:

$$
\lambda_{k}=\lambda_{10 k}+\sum_{j=1}^{n} \lambda_{j} p_{j k}, \quad k=1.2 \ldots \ldots
$$

Equation (3.7) indicates that the effective arrival rate into any node $k$ is equal to the arrival rate from the ontsiele world plus arrival rates from other moeles in the network.

The second system of linear equations is used to caculate the SCV of the interarival tine for two conserentive arrivals into any node in the network. which is the synthesis of the effects of the three basic operations:

$$
\left(a_{a j}^{2}=a_{j}+\sum_{i j}^{i \prime} c_{a i}^{2} b_{i, j}, \quad 1 \leq j \leq n\right.
$$

Lu Equation (3.8), $a_{j}$ and bij are constants as follows:

$$
\begin{aligned}
& a_{j}=1+w_{j}\left(\left(p_{0 j, j}^{\prime} \dot{c}_{0, j}^{2}-1\right)+\sum p_{i, j}^{\prime}\left[\left(1-p_{i j}\right)+p_{i j} p_{i}^{\prime}, r_{i}\right]\right) \\
& b_{i,}=w_{i} \mu_{i j}^{\prime} p_{i j}\left(1-p_{i}^{2}\right) \\
& x_{i}=-1+m_{i}^{-i) .5}\left(\max \left(c_{s i}^{2}, 0.2\right)-1\right) \\
& \omega_{j}-\left[1+1\left(1-\rho_{j}\right)^{2}\left(\vartheta_{j}-1\right)\right]^{-1}
\end{aligned}
$$


where

$$
\left(,-\left(\sum_{i=1 !}^{n} p r_{i, j}^{2}\right)^{-1}\right.
$$

The batching of products has an imparet. on the tirst fwo monemes of the eflective mival mates at rach node. Althongh Whitt [1983) considered batching, they assumed

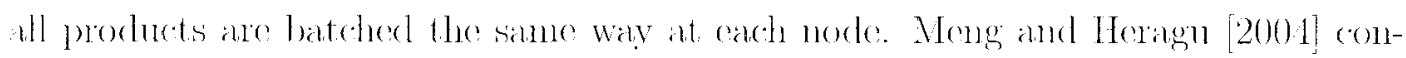
sidered a more general batching mokd and introduced a fouth network operation.

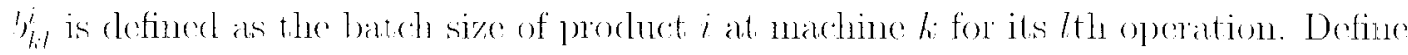
the rolative batch size:

$$
\gamma_{j i}=\frac{b_{j l}^{i}}{b_{h+1}^{n}}
$$

w the ration of the bated size of the operation of product $i$ on neste $j$ to the batede size is $(l+1)$ the opration of product $i$ on node $k$. If there are multiple products from uode j to mode te, the relative bateh size is as follows:

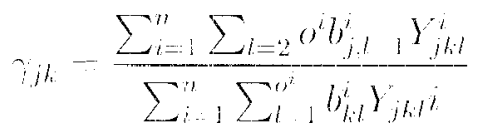

where $o^{i}$ is the mumber of operations of product 2 . The first two mements of bateh pperation at the node are

$$
\begin{aligned}
& \lambda_{a k}=\gamma_{j k} \lambda_{d j} \\
& i_{a k}^{2}=\gamma_{j k} c_{d j}^{2}
\end{aligned}
$$

By considering elifferent bated sizes in the network, the first set of lineall explations -an be morlified as follows:

$$
\hat{\lambda}_{k}=\hat{\lambda}_{1 k}+\sum_{i=1}^{\prime \prime} \lambda_{j} p_{j k} \gamma_{j k}, \quad k=1,2, \ldots n
$$


The only difference between Equation (3.12) and Equation (3.7) is the rolative bated sive that indicates the flow dhange dure to different lateh sizes for two consecentive operations (Meng and Heragu [2004]).

The second set of linear equations in MPA is as follows:

$$
c_{a k}^{2}=a_{k}+\sum_{i=1}^{n} c_{a j}^{2} b_{j k} . \quad k=1,2, \ldots n
$$

where

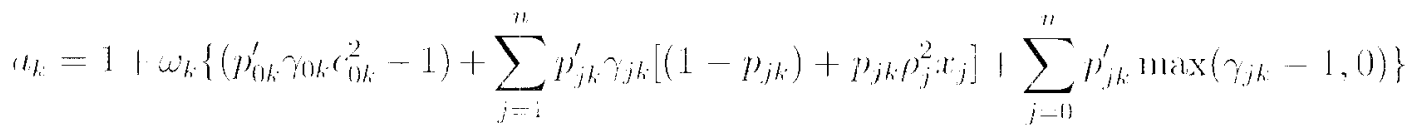

$$
\begin{aligned}
& c_{j k}=\omega_{k} p_{j k}^{\prime} p_{j k} \gamma_{j k}\left(1-r_{j}^{2}\right) \\
& \omega_{k}=\frac{1}{1+1\left(1-\rho_{k}\right)^{2}\left(u_{k}-1\right)} \\
& x_{j}=1+\frac{1}{\sqrt{m_{j}}}\left[\max \left(c_{s, j}^{2}, 0.2\right)-1\right] \\
& u_{k}=\frac{1}{\sum_{j-1(1)}^{\prime \prime}\left(p_{j k}^{\prime}\right)^{2}}
\end{aligned}
$$

anind

$$
\gamma_{j k}=\frac{\sum_{i, 1}^{b} \sum_{l=1}^{o^{\prime}} \hat{\lambda}_{j k}^{\prime} \gamma_{j k}^{i l l} Y_{j l}^{i}, Y_{k l+1}^{i}}{\sum_{l-1}^{l} \sum_{l=1}^{o^{i}} \hat{\lambda}_{j k}^{i} Y_{j l}^{i} Y_{k, l+1}^{i}}
$$

The difference between Equation (3.13) and Equation (3.8) is also due to incorporation af tihe celfect of batching.

\subsection{Estimating the first two moments of service times}

The effective mean value and SCV of service times are calculated as:

$$
\begin{aligned}
& \tau_{j}-\frac{\sum_{k=1}^{r} \sum_{l=1}^{n_{k}} \lambda_{k} \tau_{k, l} l\left\{(k, l): n_{k, l}=\frac{j\}}{j\}}\right.}{\sum_{k=1}^{r} \sum_{l-1}^{n_{k}} \lambda_{k} 1\left\{(k, l): n_{k, t}=j\right\}}
\end{aligned}
$$

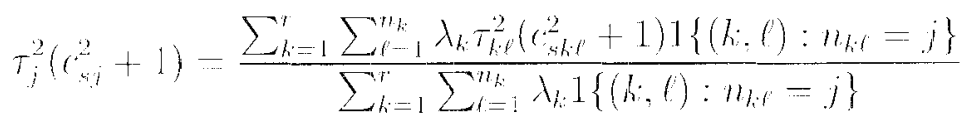




\subsection{Network performance measures}

Now that the network has been broken up into stochastically independent nodes



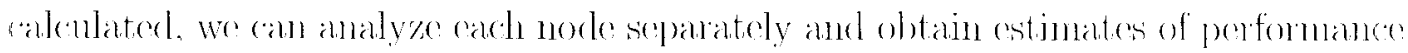
modsures ans shown noxt.

The average waiting time in a $G / / G / m$ gucue is:

$$
\mathbb{E}\left(W Q_{k}\right)-\frac{i_{n k}^{2}+c^{2}}{2} \mathbb{E}\left(W\left(Q_{k}\right)^{M / M / m}\right.
$$

whers $\mathbb{E}\left(W\left(Q_{k}\right)^{M / M / m}\right.$ is the average waiting time in a $M / M / m$ (fuence

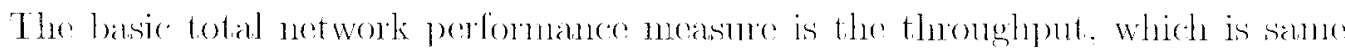
wh the tolat extemal arrival rate $\lambda_{10}$

$$
\lambda_{1 !}=\sum^{n} \lambda_{0 i}
$$

T'he mean and variance of the number of custemers $N$ in the entire network are

$$
\begin{gathered}
\mathbb{E} N=\sum_{i}^{n} \mathbb{E} N_{i} \\
V\left(n \cdot(N)=\sum_{i}^{n} \operatorname{Vur}\left(N_{i}\right)\right.
\end{gathered}
$$

T'here are two kinds of custoners: an aggregate custoner and a particular customer. For an aggregate customer, $p_{i j}$ is independent of the coment state and history of the network. On the other hand, each particular costomer should have a relatively negligible effect on the total netwonk from the view of particular constomers. MPA llses the view of aggregate colstomers.

Sonne important copations for estmating key performance measmes are listed here 
'The expected mumlere of visits to node $t$ is

$$
\mathbb{E} V_{i}=\lambda_{i} / \lambda_{1}
$$

The mean time a enstomer spends in node 2 is

$$
\mathbb{E} T_{i}=\left(\mathbb{E} V_{i}\right)\left(\tau_{i}+\mathbb{E} W_{i}\right)
$$

The expected total time in the network from arrval to departure for a custoner is

$$
\mathbb{E} T-\sum_{i}^{n} \mathbb{E} T_{i}-\sum_{i=1}^{\prime \prime} \mathbb{E} T_{i}\left(\tau,+\mathbb{E} T_{i}\right)
$$

The variance of the time spent loy a enstomes at node $i$ is

$$
\operatorname{Var}\left(T_{i}\right)=\mathbb{E} V_{i}\left(\operatorname{Var}\left(W_{i}\right)+\tau_{i}^{2} \cdot r_{i}^{2}\right)+\operatorname{Var}\left(V_{i}\right)\left(\mathbb{E} W_{i}+\tau_{i}\right)^{2}
$$

.1.1.14

$$
\mathbb{H} V_{i}^{\prime 2}=\sum_{j=1}^{n}\left(\lambda_{0 j j} / \lambda_{0}\right)\left[F\left(2 F_{d q}-1\right)\right]_{j i}
$$

where $F$ is the matrix $(I-P)^{1}$; and $P \equiv\left(p_{i j}\right)$. F $F_{d y}$ is the $n \times n$ matrix with all

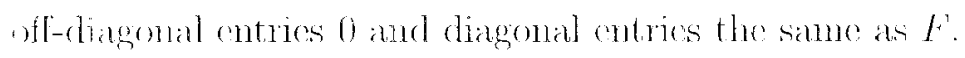

By assmung that tis at the different noden are conditionally indepentent.

$$
T-\left(\sum_{j, 1}^{\prime \prime} \sum_{i=1}^{1 / 2} T_{h j}\right)
$$

where $T_{l, j}$ is the time for the kith visit to noke j.

Finally:

$$
\mathbb{E}\left(T^{2}\right)-\sum_{i=1}^{n} \mathbb{E}\left(\sum_{i=1}^{l} T_{h i}\right)^{2}+2 \sum_{i=1}^{n} \sum_{j=i+1}^{n} \mathbb{E}\left(\sum_{k=1}^{i} T_{k i} \sum_{i=1}^{i} T_{i j}\right)
$$


and

$$
\operatorname{Var}(T)=\mathbb{E}\left(T^{2}\right)-(\mathbb{E}(T))^{2}
$$

Hence,

$$
\operatorname{Var}(T)=\sum_{i=1} n \operatorname{Var}\left(T_{i}\right)+2 \sum_{i=1}^{n} \sum_{j=i+1}^{n} \mathbb{E}\left(T_{1 i} \mathbb{E}\left(T_{1 j}\right) \operatorname{Cov}\left(V_{i}, V_{j}\right)\right)
$$

To summarize, MPA analyzes the network system in following four steps (Meng et al. [2004]):

- Calculate the first two moments of the inter-arrival times of the aggregated product into each node.

- Calculate the first two moments of the effective service time of the aggregate product at each node.

- Calculate the performance measures of each node as a $G I / G / m$ queue.

- Calculate product-specific metrics and overall system performance. 


\section{CHAPTER I \\ SIMULATION MODEL}

\subsection{Overview}

The simblation model has been developed by using the Promodel software tool Promodel is a powerful simulation tool for simulating and analyoing all lypes of production systems. Promoded focuses on system perfommances such as resomer ut iJization, production caparity, and inventory levels. As a discrente covent simulator. Pronoded is excellent for using in assembly lines. transfer limes, flexible manulandusing systems and sor ons.

A Promodel simulation model consistis severa modules to model a real system. Main modules of a Promodel model ane contiticas. Locations, resomeres and processes. The cutitios present the tasks in the system, whil the locations dedine plades where

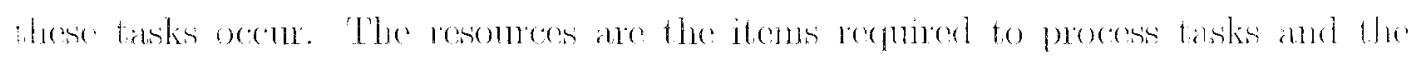

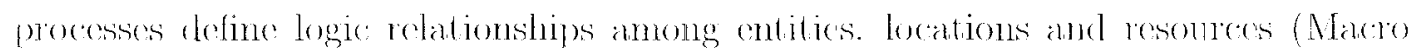
and Salnini $[2002])$.

\subsection{Model generation}

MPA (an generate a Promodel simulation model according to inpout data sherets mutomatically. The nechanism of model generation is Vismal Basic for Applications (VBA) for Mircrosoft Aceess. VBA is a macro language when Vismal basice (VB) is und within another application. VBA las the similar integrated developunent (mviromment (IDE) as VB and is adsy to be developed. 
Beranse Promodel is an otject linking and enobedeling (oLE) server, VBA can control it similar as conteol an Access object. (Canneron [1999]). A progranu written by VBA generates the simulation morlel by setting properties of every moshle from inpult diata sheets.

Tablon $4.1-4.3$ show a tyjoical set of propertios of main modules in the Promodel simulation morled generated by MPA. All propert es an be changed dymanically in different sermatios

Table 4.1. Location Propertios

\begin{tabular}{|c|c|c|c|c|c|}
\hline \multirow{2}{*}{ Locontions } & \multicolumn{5}{|c|}{ Propentios } \\
\hline & Gilfurity & Wnits & Down Tinnes & Stals & Rules \\
\hline Batteh Area (I3) & Inf & 1 & None & Timos Sories & () lelest \\
\hline (2nollo Alea (Q) & {$[111]^{\prime}$} & 1 & Nolio & Tinle Sories & () Julest. \\
\hline Sorvers $(M)$ & 1 & 1 & Uwigle & 'Tinne Sories & () lent. \\
\hline
\end{tabular}

Table 1.2. Entities Properties

\begin{tabular}{|c|cc|}
\hline Entities & \multicolumn{2}{|c|}{ Propertices } \\
\hline Product (I) & Speced & Stats \\
\hline
\end{tabular}

Table 4.3. Procosites Properties

\begin{tabular}{|c|c|c|c|c|}
\hline \multirow{2}{*}{ Procention } & \multicolumn{4}{|c|}{ Propertics } \\
\hline & Tocation & ()utput. & Destination & Rinle: \\
\hline Proctuce(I) & Batch Ara (B) & Next Procluet Type & Next Location & () ledest \\
\hline Prochet(I) & Quene Area (Q) & Next Product Typo & Next Location & (Olikst. \\
\hline Proctuct(I) & Server $(M)$ & Next Produet Type & Next Location & O)dest \\
\hline
\end{tabular}

The locations module presents servers, bateh areas and guenes in the systente. The first property of this module is capacity, which indicates the adpacity of servers as

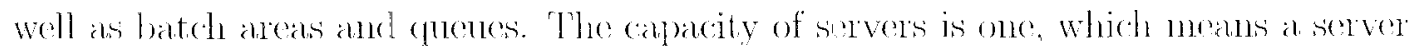

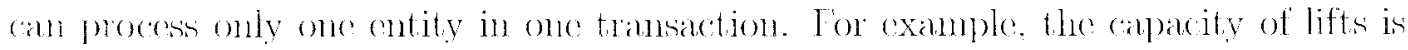
one, which means a lift can only take one pallet per tine. The capacity of batuede 
areas and queues are infinity as default values, which is a reasonal) a assiunption in AVS/RS. This property is usually kept constant.

The second property is mit, which indicates the number of ach type of server. batch area and quene. For batch areas and quenes, the defant nuit value is 1 , which is reasomable to assune there is only one batch area and waiting quene in fiont of ach type of server.

The down times and stats properties are same if there is no particular requirement. The ruks property delines how a location selects the next incoming entity from several entities that are waiting to enter this location, low multiple rntities at a location (quene for ontput, and which unit of a multi-unit location is selected by an incoming entity. There are many rules that can be selected, such as oldest by priority, ranchom and least arailable capacity. The oldest by priority is chosen as the rlofanlt value.

The entities module presents pallets in AVS/RS. Two properties need to bo sot in this module: speed and stats. The speed applies to self-moving entities. In AVS/RS, pallets are transported by vehicles and lifts. However, because vehicles and lifts ane trated as servers by queuing notwork theory, pallets "move" betwoen servers. As a result. the speed can be set to be the same for all types of pallets. The defanlt value of stats is time series.

The processes module defines the routing of entitios throngh the system and the pperations at ach location in the route. Location, output, destination and rules properties need to be set in this module.

The location property defines the location where the ontity is. The output property is the type of entity after leaving the location. Because split and superposition operations are not considered in this case study system, the ontput ploperty can be iet as the same product type. The destination is the next location the cutity will enter. For cxanple, the antomomous vehicho takes a pallet to the lift bank, then the 
destination of this pallet is the batch area of the lift bank. The rules property is sane in the location module, and the defant value is oldest by priority. 


\section{CHAPTER 5}

\section{APPLICATION OF MPA IN AVS/RS}

MPA was designed for a discrete pirts mannfacturing system. It needs to be modified to be applied to the AVS/RS. Main changes of MPA are listed in Talbles 5.1 $-5.3$.

Table 5.1. Sorver parameters

\begin{tabular}{|c|c|}
\hline Parameter & Moanng \\
\hline$m$ & Unique vehiche or lift index number in the systen \\
\hline$\theta$ & Coll number \\
\hline loc & Locations of ve icles or lifts \\
\hline copucity & Number of the volicie or lift type in the cell \\
\hline type & Server type \\
\hline MTTF & Mean time to failure of the server \\
\hline$M T T R$ & Mean time to rejair the server \\
\hline$N_{s}$ & The server needs to be setup after $N$ s londs \\
\hline$T_{s}$ & Setup time of the server \\
\hline$r_{T}^{2}$ & $\mathrm{SCV}$ of $T S$ \\
\hline
\end{tabular}

Tablo 5.2. Product parameters

\begin{tabular}{|c|c|}
\hline Parameter & Meaning \\
\hline$p$ & Product inclex \\
\hline$\lambda_{p}$ & Arrival rate of product $p$ from the ontside workd \\
\hline$\cdot i_{1}^{2}$ & $\mathrm{SCV}$ if $\lambda_{l}$ \\
\hline$t_{1}$ & Mean setup time of product $p$ on the material handling device \\
\hline$\sqrt{2}$ & $\mathrm{SCV}$ of $t_{p}$ \\
\hline
\end{tabular}

We assinne ach storage space on each tier to be a server, where loaks anc storch for a randon time period. However, performance of storage areas ane not consirtered in this paper, because they aro not meaningful in measming the perfomance of an AVS/RS. 
Table 5.3. Parmeters for operations

\begin{tabular}{|c|c|}
\hline Parameter & Meaning \\
\hline$p$ & Product index \\
\hline o & Operation index of product $p$ \\
\hline$m$ & Absolute server index \\
\hline$b$ & Batch size of cach server \\
\hline$t_{0}$ & Natural service time of cach operation for product $p$ \\
\hline$c_{1,}^{2}$ & SCV of $t_{0}$ \\
\hline$t_{s}$ & Mean setup tine of every server for cach operation \\
\hline$a^{2}$ & $\mathrm{SCV}$ of $t_{4}$ \\
\hline
\end{tabular}

MPA is a complex network analyzer with many functions. In order to apply MPA to estimate performance of an AVS/RS, some paraneters in MPA ane simplified with some defanlt values. For cxample, although it can be relaxed, the assumption has been made that the MTTFs and the MTTRs are equal in the system studied in this thesis. Adelitionally, Ths are assumed to be o for all servers in the system. All SCV s are assumed to be 1. which indicates only exponential distribution is contidered. 
CHAPTER 6

\section{WEB INTERFACE FOR THE CONCEPTUALIZATION OF AVS/RS AND AS/RS}

\subsection{Introduction of the web interface}

Analytical modeling of warchonse design is an altermative to simulation. The analytical model and significantly reduce the time to restablish the warehouse resign. However, if the analytical models reside on a local computer, and nese sperifie software, for example, Mathlat, it is diffient for warchonse designers who do low have the

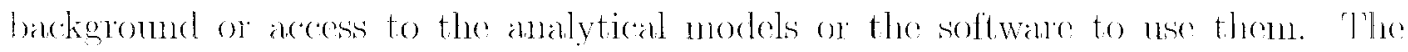
web based tool presented in the thesis provides a nser-friendly interface botwen the analytical models and warehonse designers. Users need not know dedails of the mlgorithm used to solve the analytical models. The main function of the on-line interfare is to help warchouse designers to quickly cvaluate alternate designs by uning t.he conceptualization tools developed to analyze AS/RS and AVS/RS. Fonn different algonithms for AVS/RS and AS/RS are mubeded in the website, and can be unerl for different system design requirements.

\subsubsection{Basic technologies to develop the web interface}

The wo interface is based on a browser/server (B/S) system conliguration. Applicat

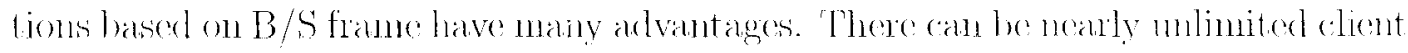

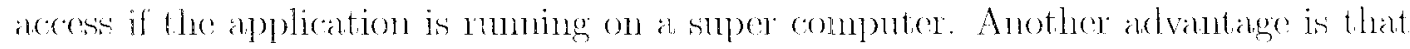
1.he application only needs to be changed on the sover side instead of changing thonbands of aient-installed applications. The drawback of B/S configuration comprared 
10 another configuation, for example the client/server $(\mathrm{C} / \mathrm{S})$ is that all calculations need to be (omputed on the server computer, which may lead to kata blocking. In one application, analytical nodels do not require much computation time, and thens Her B/S romfiguration is suitahle in developing this interface.

Many webpage langlages existed in the maket, and wo chose the Java berver

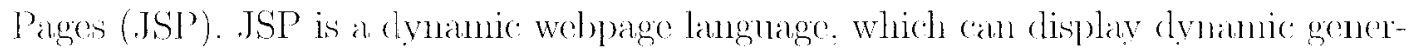
ated content. This langnage has several advantages including ability to function on any web server, separating the realization logic from the appearance of pages, and allowing real-time developunent.

The website has a real-time database to store wer information and clesign dalat. We chose MySQL tedmology to develop this dataluase. MySQL hab many advantagess. The first one is flexibility. MySQL only needs one mega byte of data storage to rmu the datalbase itsclf. As a result, MySQI movides mud flexibility. MySQL is an opensomere application allowing developers to add micpue recpirenents to the database server. The second advantage is high perfomanes and reliability. A clatabase on the server computer shombl bestatic and able to handle some data crom. Mys(QL provides strong alata protection and exceptional security features to cusme the wobsite nums is intencled.

\subsubsection{Details of the web interface}

The process by which the user enters data can be divided into theo steps:

- Provide nser information

- Select an algorithn and enter required parancters

Rum the algorithn and compare results.

Figune 6.1 shows the data entry process of the wob interlinec. 




Figure (6.1. Doitia cutry steps

\subsection{Case studies}

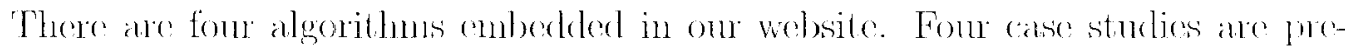
ienterel in this section.

1) AS/RS_m algoritim:

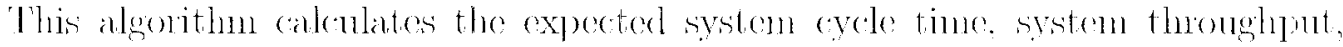
cane utilization and total system cost for an AS/RS when the total storage space recuirement is given.

Tables 6.1 and 6.2 show the list of input and ontput paraneters of AS/RSim algoritlm.

Table 6.1. homen paranoters of AS/RS_m algorithm

\begin{tabular}{|c|c|}
\hline Paraneter & Meaning \\
\hline Rs & Arival rate of storage request (arrivalls per mintute) \\
\hline $\mathrm{Rr}$ & Arrival rate of retrieval reepuest (arrivals per mimute) \\
\hline $\mathrm{T}$ & Total number of tiens in the warehomise \\
\hline$\Lambda$ & Total number of aisles in the warchonse \\
\hline 11 & Total storage space repuirement \\
\hline$\overline{\mathrm{CBC}}$ & Lower bound on the total number of rack eolumns \\
\hline $1 \overline{B C}$ & Upene bound on the total number of rarek colnumins; \\
\hline $11 \overline{\mathrm{H}}$ & The height of each storage spare \\
\hline $11 \mathrm{~L}$ & The wirth of and storage sparer \\
\hline $\mathrm{V}$ & Velicele lorizontal spoed \\
\hline $\mathrm{V} 1$ & Vohicle/lift vortical spoed \\
\hline Cost Crane & Cost per crane in thonsands of alollats \\
\hline Cost_Cell & Cost per rack cell in thomsand of dollats \\
\hline
\end{tabular}


Table 6.2. Output parameters of AS/RS_nn algorithun

\begin{tabular}{|c|c|}
\hline Parameter & Meaning \\
\hline $\mathrm{C}$ & Total number of columns of the rack \\
\hline $\mathrm{U}$ & Crane utilization \\
\hline ECT & Expected system cycle time \\
\hline Cost & The total estimated cost of the system \\
\hline
\end{tabular}

Table 6.3 shows a studly case using the AS/RS_m algorithm. These parameters are divided into six parts. The rack configuration denotes the basic clesign parancters of the warehouse, such as the number of aisles and number of ticrs. The $S / R$ machine speed defines the horizontal and vertical speeds of the $S / R$ crane. The transaction arrival rate involves two types of arrival rate: storage and retrieval requests. The total space requirement is required in this algorithnn. The cost consists of two parts: the cost of a crane and the cost of a storage cell. The algorithn can calculate the optimal system cost using these data.

Table 6.3. A study case using the AS/RS_m algorithm

\begin{tabular}{|c|c|}
\hline Paraneter & Value \\
\hline Rs & 0.5 \\
\hline Rr & 0.5 \\
\hline $\mathrm{T}$ & 15 \\
\hline $\mathrm{A}$ & 10 \\
\hline $\mathrm{u}$ & 30000 \\
\hline $\mathrm{LBC}$ & 10 \\
\hline $\mathrm{UBC}$ & 200 \\
\hline $\mathrm{uH}$ & 6 \\
\hline $\mathrm{uL}$ & 5 \\
\hline Vv & 600 \\
\hline VI & 200 \\
\hline Cost_Crane & 350 \\
\hline Cost_Cell & 0.1 \\
\hline
\end{tabular}

Figure 6.2 shows the imput page of AS/RS_m algorithm. Figure 6.3 shows the output page of AS/RS.m algorithm.

2) AS/RS_mo algorithm: 


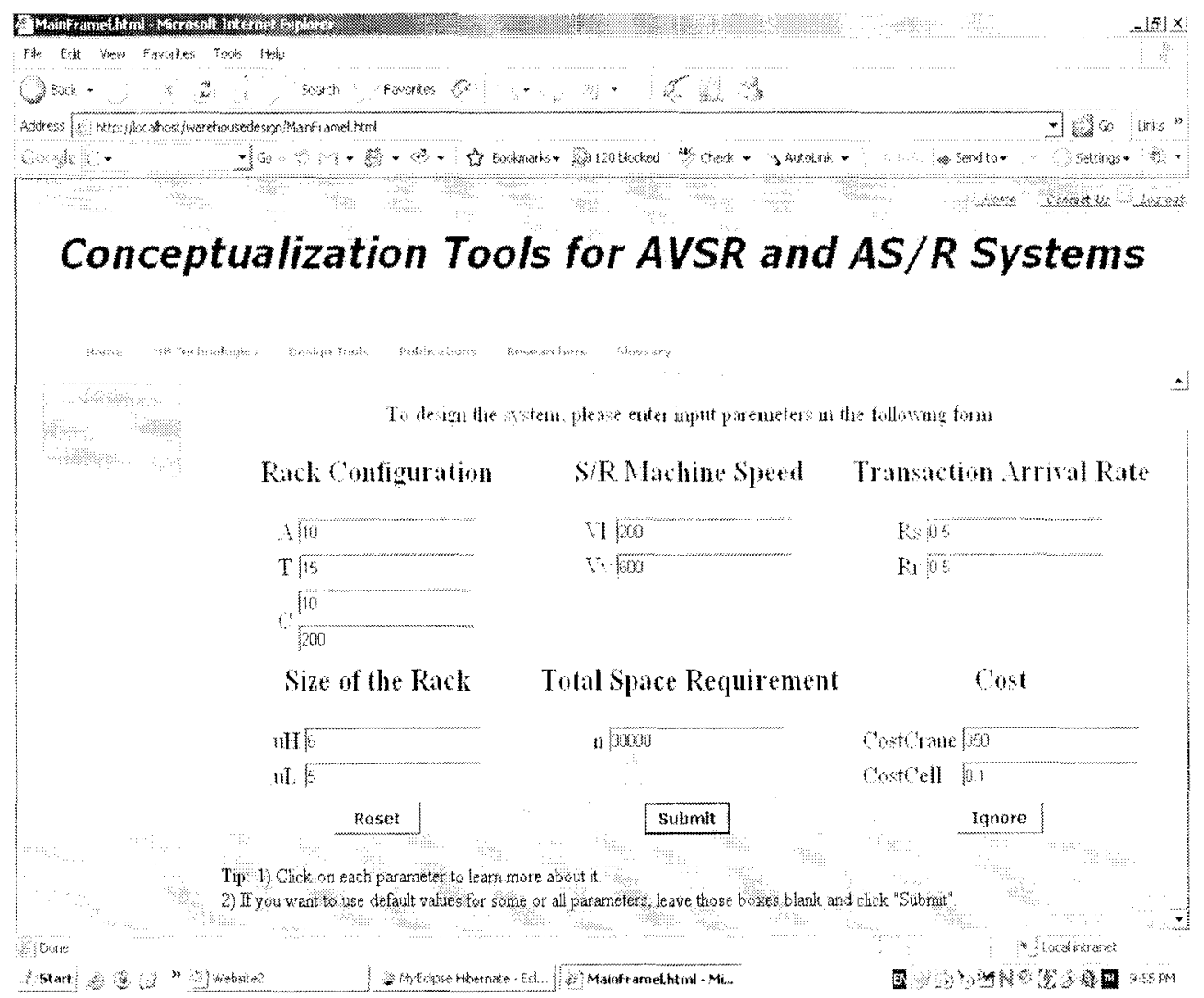

Figure 6.2. Input paraneters page of AS/RS_m algorithm

This algorithm also calculates the expected system cycle timo, system throughput, crane ntilization and total system cost for an AS/RS. The only difference between this algorithm and AS/RS_m algorithm is that the number of colmmms is mequired instead of the total storage space requirement.

Tables 6.1 and 6.5 show the list of input and output parameters of AS/RS mnc algorithm. Table 6.6 shows a study case of AS/RS_mo algorithm. Figure 6.4 shows the input page of AS/RS mne algorithm and Figure 6.5 shows the ontput page of AS/RS_me algoritlin.

3) AVS/RS_mn algorithm:

This algorithm calculates the expected system cycle time, systen thronghput, lift ntilization, vehicle utilization and total systen cost for an AVS/RS. 




Figure 6.3. Output parameters page of AS/RS m algorithm

Table 6.4. Input parameters of AS/RS_mc algorithm

\begin{tabular}{|c|c|}
\hline Parameter & Meaning \\
\hline $\mathrm{Rs}$ & Arrival rate of storage request (arrivals per mimute) \\
\hline $\mathrm{Rr}$ & Arrival rate of retrieval request (arrivals per minute) \\
\hline $\mathrm{T}$ & Total number of tiers in the warehouse \\
\hline $\mathrm{A}$ & Total number of aisles in the warchouse \\
\hline $\mathrm{C}$ & Total number of columins in the warchouse \\
\hline $\mathrm{uH}$ & The height of each storage space \\
\hline $\mathrm{uL}$ & The width of each storage space \\
\hline $\mathrm{Vv}$ & Velincle horizontal spced \\
\hline $\mathrm{Vl}$ & Vehicle/lift vertical speed \\
\hline Cost_Crane & Cost per crane in thousands of dollars \\
\hline Cost_Cell & Cost per rack cell in thousands of dollars \\
\hline
\end{tabular}

Tables 6.7 and 6.8 show the list of input and output parameters of AVS/RS_m algorithm. Table 6.9 shows a case study using the AVS/RS m algorithri. The horizontal speed is the antonomous vehicle speed, and the vertical speed is the lift speed. 
Table 6.5. (output parameters of AS/RS_me algorithm

\begin{tabular}{|c|c|}
\hline Parmeter & Meaning \\
\hline $\mathrm{U}$ & Crane utilization \\
\hline ECT & Expected system cycle tinno \\
\hline Cost & The total estimated cost of the system \\
\hline
\end{tabular}

Tahle 6.6. A study ase of using the AS/RS_nuc algonithn

\begin{tabular}{|c|c|}
\hline Parameters & Value \\
\hline $\mathrm{R} s$ & 0.5 \\
\hline $\mathrm{Rr}$ & 0.5 \\
\hline $\mathrm{T}$ & 15 \\
\hline $\mathrm{A}$ & 10 \\
\hline $\mathrm{C}$ & 100 \\
\hline $\mathrm{uH}$ & 6 \\
\hline $\mathrm{ul} \mathrm{L}$ & 5 \\
\hline $\mathrm{V} v$ & 600 \\
\hline $\mathrm{Vl}$ & 200 \\
\hline Cost_Crano & 350 \\
\hline Cost_Cell & 0.1 \\
\hline
\end{tabular}

Figure 6.6 shows the input page of AVS/RS m algorithm. Figure 6.7 shows the output page of AVS/RS.m algorithm.

4) AVS/RS me algorithm

This algorithm also calculates the expected system cycle time, system throughput, lift ntilization, vehicle ntilization and total systen cost for an AVS/RS. The only difference between this algorithm and AVS/RS_n algorithn is that the mumber of columns is required instead of the total storage space requirement.

Tables 6.10 and 6.11 show the list of input and output paraneters of AVS/RS_nnc algorithn. Table 6.12 shows a case study of using the AVS/RS_me algorithm. Figure 6.8 shows the input page of AVS/RS_ne algorithm. Figure 6.9 shows the output page of AVS/RS_me: algorithm. 


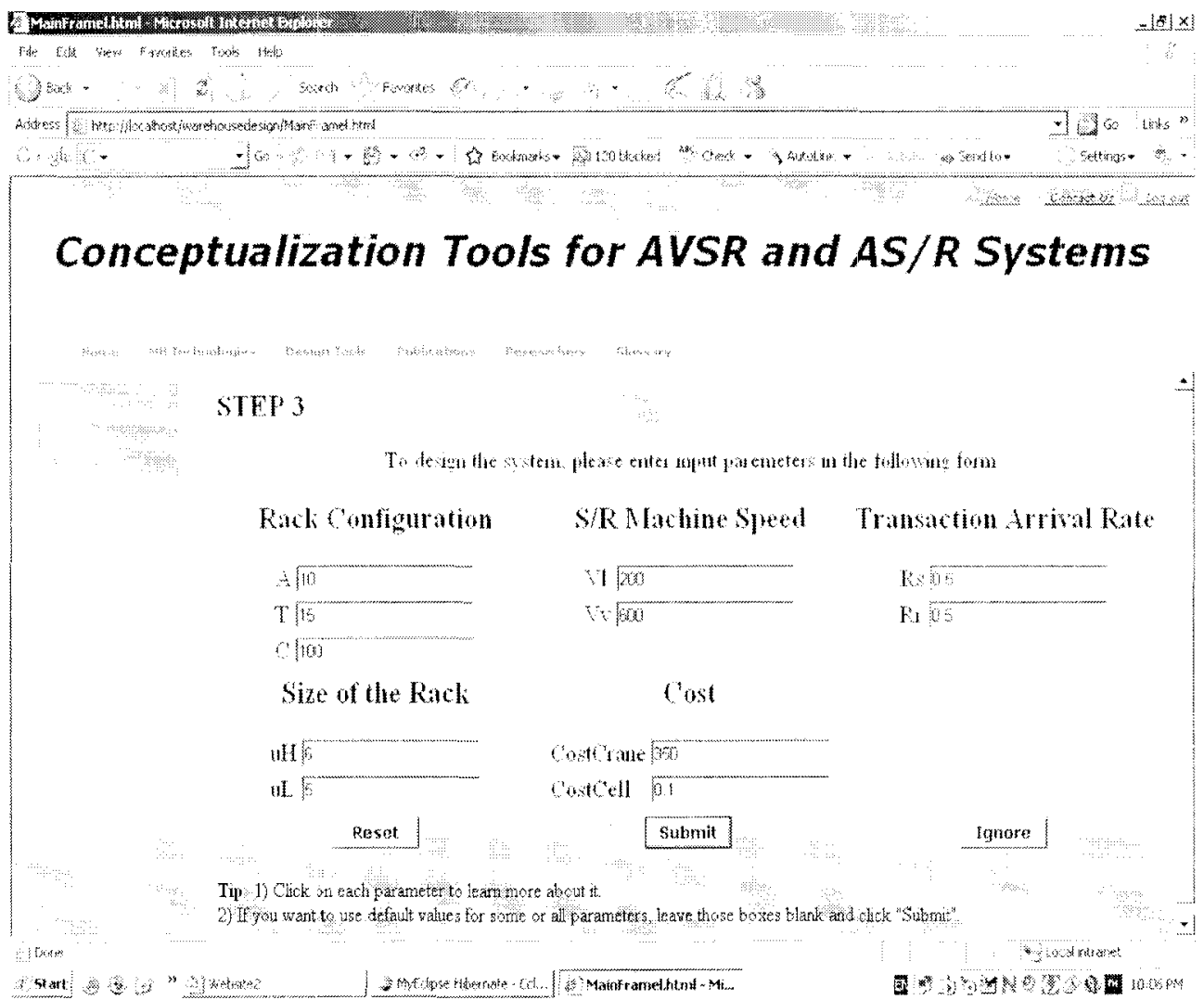

Figure 6.4. Input parancters page of AS/RS_me algorithum 




Figure 6.5. Output parameters page of AS/RS_nuc allgorithm 
Table 6.7. Input parancters of AVS/RS m algorithm

\begin{tabular}{|c|c|}
\hline Parancter & Meaning \\
\hline$R_{s}$ & Arrival rate of storage request (arrivals per nimute) \\
\hline $\mathrm{Rr}$ & Arrival rate of retrieval request (arrivals per minute) \\
\hline $\mathrm{T}$ & Total number of tiers in the warchouse \\
\hline A & Total number of aisles in the warehomse \\
\hline $\mathrm{V}$ & Total number of vehiches \\
\hline$\overline{\mathrm{T}}$ & Total number of lifts \\
\hline 11 & Total storage space requirement \\
\hline$\overline{\mathrm{LBC}}$ & Lower bound on the total number of rack eolumms \\
\hline $\mathrm{UBC}$ & Upper bound on the total number of rack columns \\
\hline $11 \mathrm{H}$ & The height of each storage space \\
\hline $11 \mathrm{D}$ & The depth of each storage space \\
\hline${ }_{11} \mathrm{~W}$ & The width of rach storage space \\
\hline $11 \bar{A}$ & The width of each aisle \\
\hline $\mathrm{Vv}$ & Vohicle horizontal spoed \\
\hline V] & Vehicle/lift vertical spoed \\
\hline Cost_V & Cost per vehicle in thousands of dollins \\
\hline Cost L & Cost per lift in thomsands of clollars \\
\hline Cost_Coll & Cost per rack coll in thousands of dollats \\
\hline
\end{tabular}

Table 6.8. Output parameters of AVS/RS_m algorithum

\begin{tabular}{|c|c|}
\hline Parameter & Meaning \\
\hline C & Total number of colmums of the rack \\
\hline UL & Lift ntilization \\
\hline WQL & Average waiting time for an available lift \\
\hline UV & Vehicle ntilization \\
\hline ECT & Expected system cycle time \\
\hline Cost $\Lambda$ ll & The total estimated cost of the systen \\
\hline
\end{tabular}




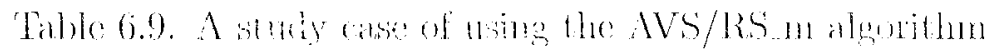

\begin{tabular}{|c|c|}
\hline Piramede! & Value \\
\hline$R_{S}$ & 0.5 \\
\hline $\mathrm{Rr}$ & 0.5 \\
\hline$T$ & 1 \\
\hline$\Lambda$ & 10 \\
\hline$V$ & 3 \\
\hline $\mathrm{T}$ & 2 \\
\hline i) & 100000 \\
\hline $\mathrm{IBC}$ & 10) \\
\hline $\mathrm{UBC}$ & 200 \\
\hline ulI & 6 \\
\hline 111$)$ & 1.5 \\
\hline $11 \mathrm{~W}$ & 5 \\
\hline$i \mathrm{~A}$ & 2 \\
\hline$V_{V}$ & 100 \\
\hline $\mathrm{V} !$ & 200 \\
\hline Cost_V & 250 \\
\hline Cost $\mathrm{L}$ & 50 \\
\hline Cost_Cell & 0.5 \\
\hline
\end{tabular}

Table 6.10. Input parameters of AVS/RSAme algotitim

\begin{tabular}{|c|c|}
\hline Piarmeter & Meaning \\
\hline Rs: & Arrival rate of stomge repuest (arrands per minule) \\
\hline $\operatorname{Rr}$ & Arrival late of retrieval represt (arrivals per minute) \\
\hline $\mathrm{T}$ & Total mumber of tiens in the wallohomse \\
\hline A & 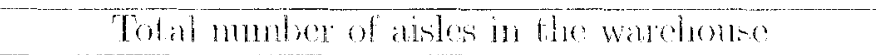 \\
\hline V & Total number of wolictes \\
\hline l. & Total mumber of lifis \\
\hline C & Total number of rack collumms \\
\hline 1111 & The hoight of areh storage spare \\
\hline $11 \mathrm{D}$ & The depth of ache storage spare \\
\hline$\overline{11 W}$ & The wielth of cacti storage space \\
\hline $11 \mathrm{~A}$ & The wirlth per aisle \\
\hline Vv & Vehido horisontal speced \\
\hline Vi & Voliche/lift vertical speexl \\
\hline Cust $y$ & Cost per voluche in thousinds of dollats \\
\hline Cost $L$ &  \\
\hline Cost Coll & Cost ver rack cell in thourands of dolliat \\
\hline
\end{tabular}




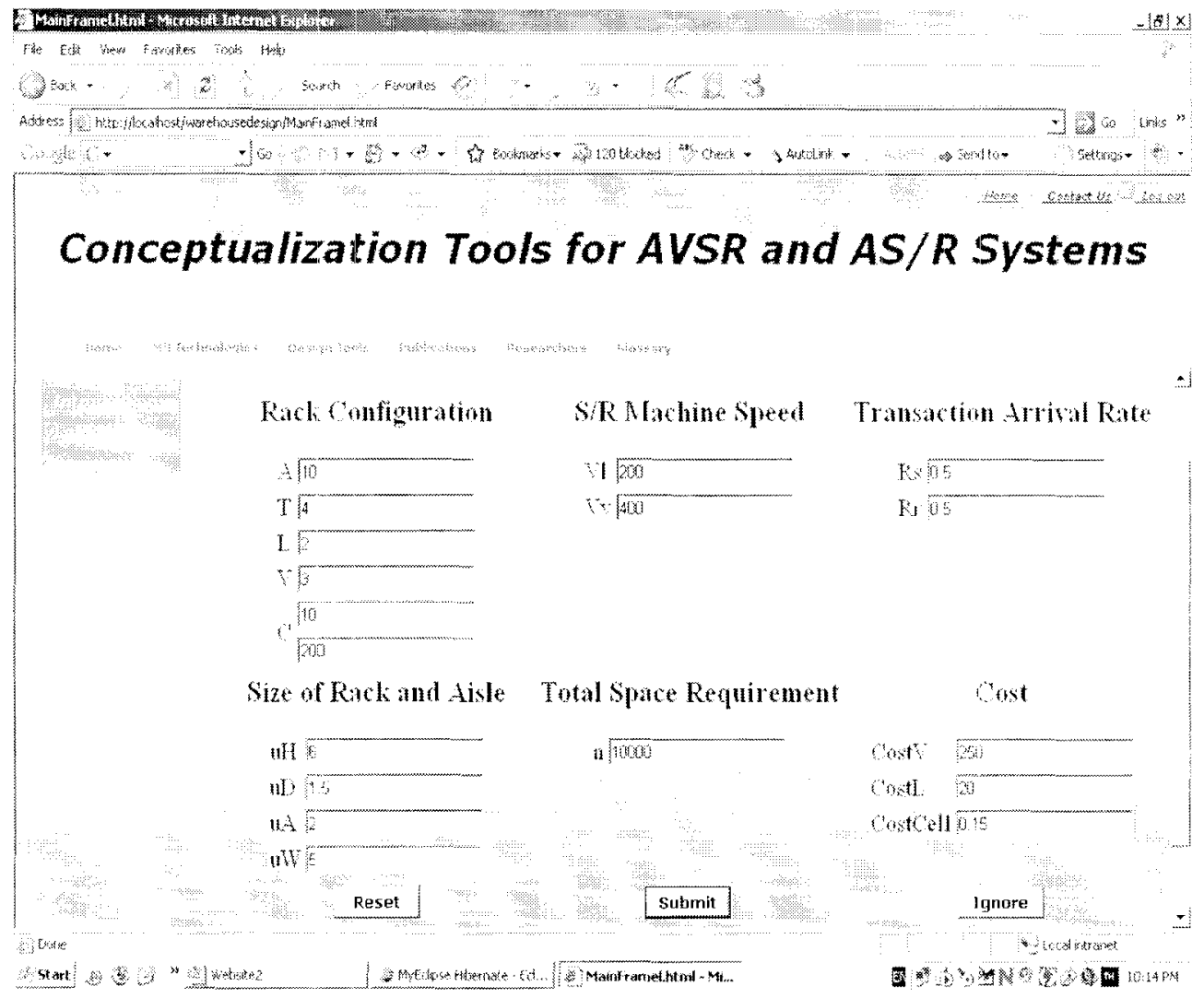

Figure 6.6. Input paraneters page of AVS/RS_un algorithm.

Table 6.11. Output paraneters of AVS/RS_nnc algorithm

\begin{tabular}{|c|c|}
\hline Parameter & Meaning \\
\hline UL & Lift utilization \\
\hline WQL & Average waiting time for an availalole lift \\
\hline UV & Vehicle utilization \\
\hline ECT & Expected system cycle tirne \\
\hline CostAll & The total estimated cost of the systen \\
\hline
\end{tabular}






Figure 6.7. Output parancters page of AVS/RS_m algorithm Table 6.12. A study case of using the AVS/RS_me algorithm

\begin{tabular}{|c|c|}
\hline Paraneters & Valuc \\
\hline Rs & 0.5 \\
\hline $\mathrm{Rr}$ & 0.5 \\
\hline $\mathrm{T}$ & 4 \\
\hline $\mathrm{A}$ & 10 \\
\hline V & 3 \\
\hline $\mathrm{L}$ & 2 \\
\hline $\mathrm{C}$ & 100 \\
\hline uII & 6 \\
\hline $11 \mathrm{D}$ & 1.5 \\
\hline${ }_{11} \mathrm{~W}$ & 5 \\
\hline $11 \mathrm{~A}$ & 2 \\
\hline Vv & 400 \\
\hline $\bar{V} 1$ & 200 \\
\hline Cost_V & 250 \\
\hline Cost_L & 50 \\
\hline Cost Cell & 0.15 \\
\hline
\end{tabular}






\section{Conceptualization Tools for AVSR and AS/R Systems}

Rack Configuration SR Machine Speed Transaction Arrival Rate
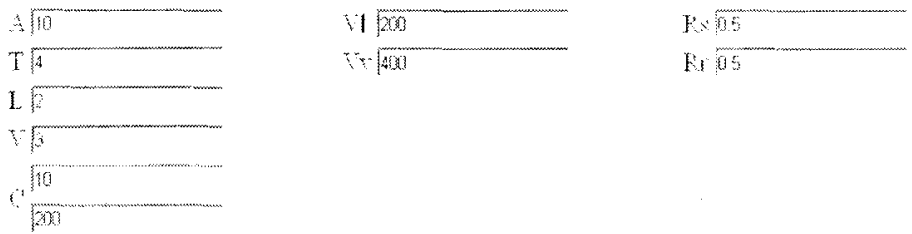

Size of Rick and Aisle Total Space Requirement
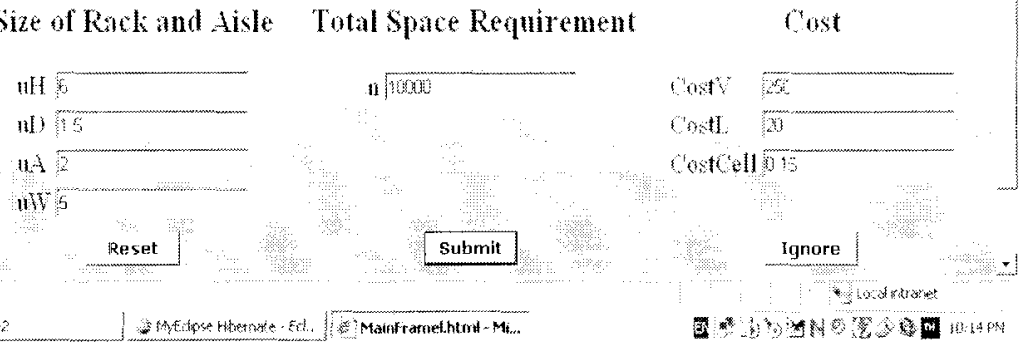

n)

Figure 6.8. Input parameters page of AVS/RS_mo algorithm 




\section{Conceptualization Tools for AVSR and AS/R Systems}

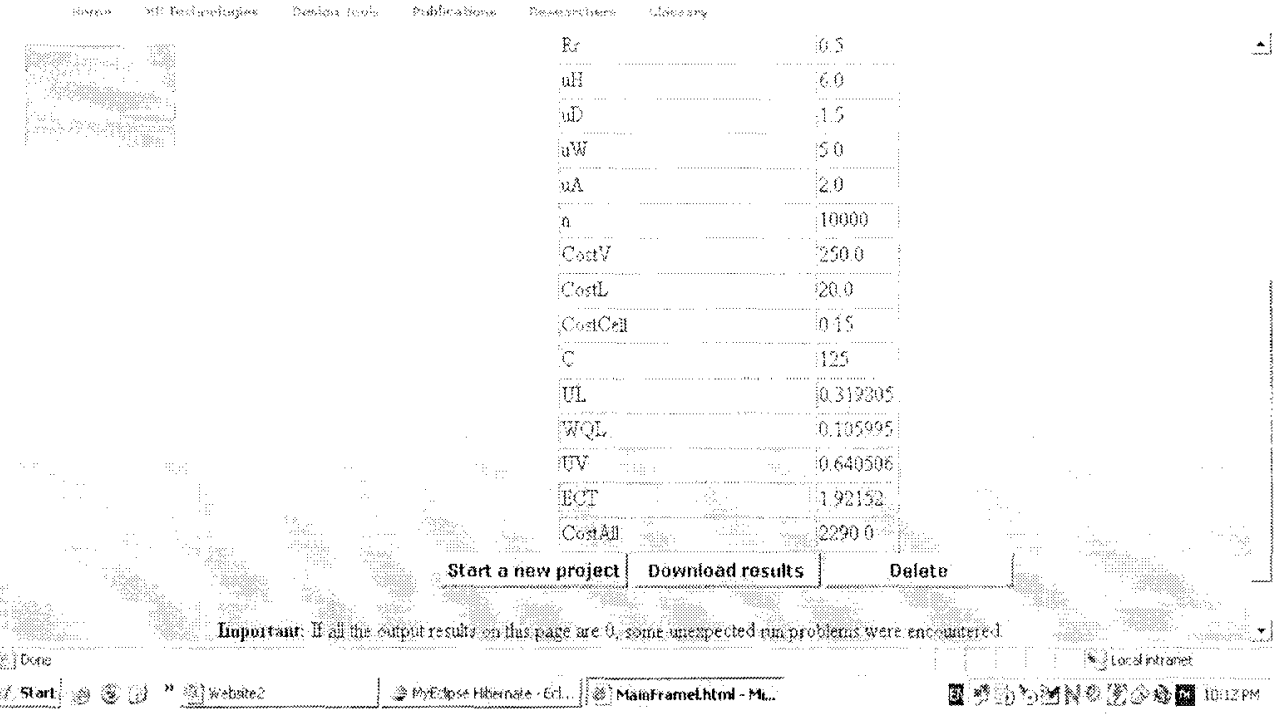

Figure 6.9. Output parameters page of AVS/RS_me algorithm 


\section{CHAPTER 7}

\section{EXPERIMENTS AND DISCUSSION}

\subsection{Comparison between MPA and simulation}

\subsubsection{Experimental design}

In this section, an initial design is analyzed first, and several design improvenents are proposed. Results of MPA are compared with those of simulation.

Tahle 7.1 shows the operation scquences and external arrival rates for nine products. $S_{1}$ refers to the autonomous vchicle in the receiving area, and $S_{2}$ is the autonomous vehicle in the shipping area. $S_{3}$ is the lift in lift bank that can transport pallets between different tiers. $S_{4}, S_{5}$ and $S_{6}$ are autonomous vehicles on the three storage tiers, and $S_{7}, S_{8}$ and $S_{9}$ are storage areas on the three tiers. The number of vehicles and lifts can be rnodified to meet the throughput and other perfomanee refuirements. There are three storage tiers in this system, but more tiers can be added casily.

Table 7.1. Operation sequences and external arrival rates for nine products

\begin{tabular}{|c|c|c|c|}
\hline Product & Storage Sequence & Retrieval Sequence & Arrival rate (per minin) \\
\hline$P_{1}$ & $S_{1} \rightarrow S_{3} \rightarrow S_{4} \rightarrow S_{7}$ & $S_{7} \rightarrow S_{4} \rightarrow S_{3} \rightarrow S_{1}$ & 0.4 \\
\hline$P_{2}$ & $S_{1} \rightarrow S_{3} \rightarrow S_{5} \rightarrow S_{8}$ & $S_{8} \rightarrow S_{5} \rightarrow S_{3} \rightarrow S_{3}$ & 0.1 \\
\hline$P_{3}$ & $S_{1} \rightarrow S_{3} \rightarrow S_{6} \rightarrow S_{9}$ & $S_{9} \rightarrow S_{6} \rightarrow S_{3} \rightarrow S_{1}$ & 0.1 \\
\hline$P_{1}$ & $S_{1} \rightarrow S_{3} \rightarrow S_{4} \rightarrow S_{7}$ & $S_{7} \rightarrow S_{4} \rightarrow S_{3} \rightarrow S_{1}$ & 0.4 \\
\hline$P_{8}$ & $S_{1} \rightarrow S_{3} \rightarrow S_{5} \rightarrow S_{8}$ & $S_{8} \rightarrow S_{5} \rightarrow S_{3} \rightarrow S_{3}$ & 0.4 \\
\hline$P_{6}$ & $S_{1} \rightarrow S_{3} \rightarrow S_{6} \rightarrow S_{9}$ & $S_{9} \rightarrow S_{6} \rightarrow S_{3} \rightarrow S_{1}$ & 0.4 \\
\hline$P_{7}$ & $S_{1} \rightarrow S_{3} \rightarrow S_{4} \rightarrow S_{7}$ & $S_{7} \rightarrow S_{4} \rightarrow S_{3} \rightarrow S_{1}$ & 0.4 \\
\hline$P_{8}$ & $S_{1} \rightarrow S_{3} \rightarrow S_{5} \rightarrow S_{8}$ & $S_{8} \rightarrow S_{5} \rightarrow S_{3} \rightarrow S_{3}$ & 0.4 \\
\hline$P_{9}$ & $S_{1} \rightarrow S_{3} \rightarrow S_{6} \rightarrow S_{9}$ & $S_{9} \rightarrow S_{6} \rightarrow S_{3} \rightarrow S_{1}$ & 0.1 \\
\hline
\end{tabular}


Table 7.2 presents the operation time $\left(t_{o}\right)$ for cach operation, and the time unit is minute. Because $S_{3}, S_{4}$ and $S_{5}$ are antonomous vehicles on the three tiers, the $S / R$ times are different. However, assuming storage operation time is equal to retrieval operation time for every server is rcasonable for the AVS/RS.

Tahle 7.2. Product operation times

\begin{tabular}{|c|c|c|c|c|c|c|c|c|c|}
\hline$P / S$ & $S_{1}$ & $S_{2}$ & $S_{3}$ & $S_{4}$ & $S_{5}$ & $S_{6}$ & $S_{7}$ & $S_{8}$ & $S_{9}$ \\
\hline$P_{1}$ & 0.2 & 0.3 & $0.1 / 0.1$ & $0.3 / 0.3$ & & & 2 & & \\
\hline$P_{2}$ & 0.2 & 0.2 & $0.1 / 0.1$ & & $0.3 / 0.3$ & & & 3 & \\
\hline$P_{3}$ & 0.2 & 0.2 & $0.1 / 0.1$ & & & $0.3 / 0.3$ & & & 6 \\
\hline$P_{4}$ & 0.2 & 0.2 & $0.1 / 0.1$ & $0.3 / 0.3$ & & & 2 & & \\
\hline$P_{5}$ & 0.2 & 0.2 & $0.1 / 0.1$ & & $0.3 / 0.3$ & & & 3 & \\
\hline$P_{6}$ & 0.2 & 0.2 & $0.1 / 0.1$ & & & $0.3 / 0.3$ & & & 6 \\
\hline$P_{7}$ & 0.2 & 0.2 & $0.1 / 0.1$ & $0.3 / 0.3$ & & & 2 & & \\
\hline$P_{8}$ & 0.2 & 0.2 & $0.1 / 0.1$ & & $0.3 / 0.3$ & & & 3 & \\
\hline$P_{9}$ & 0.2 & 0.2 & $0.1 / 0.1$ & & & $0.3 / 0.3$ & & & 6 \\
\hline
\end{tabular}

\subsubsection{Experimental results and discussion}

Different dosigns and results are presented next.

Scenario 1 (Initial Design):

Three types of products are stored in three different ticrs with arrival rate 0.2 transactions per minute. The number of each type of server is one. Table 7.3 shows results of queue lengths in front of the servers, number of customers waiting and being processed at the servers, and the utilization of scrvers for scenario 1 .

Table 7.3. Results for scenario 1

\begin{tabular}{|c|ccc|cccc|ccc|}
\hline \multirow{3}{*}{$S$} & \multicolumn{3}{|c|}{$L_{q}$} & \multicolumn{3}{|c|}{$L$} & \multicolumn{3}{|c|}{ Utilization } \\
& MPA & Simul & Diff & MPA & Simu & Diff & MPA & Simu & Diff \\
\hline$S_{1}$ & 0.040 & 0.078 & 0.486 & 0.280 & 0.316 & 0.113 & 0.210 & 0.239 & 0.004 \\
$S_{2}$ & 0.015 & 0.031 & 0.195 & 0.175 & 0.188 & 0.066 & 0.160 & 0.157 & 0.004 \\
$S_{3}$ & 0.025 & 0.691 & 0.964 & 0.545 & 0.563 & 0.033 & 0.520 & 0.515 & 0.008 \\
$S_{4}$ & 0.038 & 0.088 & 0.567 & 0.278 & 0.333 & 0.164 & 0.240 & 0.214 & 0.017 \\
$S_{5}$ & 0.362 & 0.674 & 0.463 & 0.922 & 1.234 & 0.252 & 0.559 & 0.559 & 0.001 \\
$S_{6 j}$ & 0.009 & 0.018 & 0.488 & 0.129 & 0.134 & 0.038 & 0.120 & 0.116 & 0.003 \\
\hline
\end{tabular}


Scenario 2:

The utilization of servers in the initial design is low, which means the material handling system capacity is not utilized adequately. In scenario 2. the arrival rates is increased to test if the utilization can be improved. The nunbor of product types is still kept at three and the number of each type of server remains at one, while the arrival rates of products are higher (0.5 transactions per minute). Table 7.4 shows lesults for scenario 2 .

Table 7.4. Results for scenario 2

\begin{tabular}{|c|ccc|ccc|ccc|}
\hline \multirow{3}{*}{$S$} & \multicolumn{3}{|c|}{$L_{q}$} & \multicolumn{3}{c|}{$L$} & \multicolumn{3}{c|}{ Utilization } \\
& MPA & Simn & Diff & MPA & Sinnu & Diff & MPA & Simu & Diff \\
\hline$S_{1}$ & 0.395 & 0.394 & 0.005 & 0.845 & 0.841 & 0.006 & 0.450 & 0.447 & 0.007 \\
$S_{2}$ & 0.130 & 0.153 & 0.151 & 0.430 & 0.451 & 0.046 & 0.300 & 0.298 & 0.008 \\
$S_{3}$ & 10.36 & 9.165 & 0.095 & 11.26 & 10.36 & 0.087 & 0.900 & 0.895 & 0.006 \\
$S_{4}$ & 0.906 & 0.977 & 0.072 & 1.506 & 1.572 & 0.042 & 0.600 & 0.595 & 0.008 \\
$S_{5}$ & 1.644 & 1.373 & 0.197 & 2.344 & 2.066 & 0.134 & 0.700 & 0.693 & 0.010 \\
$S_{6}$ & 0.144 & 0.158 & 0.090 & 0.444 & 0.456 & 0.028 & 0.300 & 0.298 & 0.005 \\
\hline
\end{tabular}

Scenario 3:

By checking results of scenario 2, it is found that the utilization of lift is $90 \%$, which may impact the robustness of the system. One solution is to increase the number of lifts to decrease the chance of blocking in the lift bank and improve system performance. The number of lifts increases from one to two. Table 7.5 shows results of scenario 3 .

Table 7.5. Results for scenario 3

\begin{tabular}{|c|ccc|ccc|ccc|}
\hline \multirow{3}{*}{$S$} & \multicolumn{3}{|c|}{$L_{q}$} & \multicolumn{3}{|c|}{$L$} & \multicolumn{3}{|c|}{ Utilization } \\
& MPA & Simu & Diff & MPA & Simu & Diff & MPA & Simu & Diff \\
\hline$S_{1}$ & 0.395 & 0.386 & 0.025 & 0.845 & 0.835 & 0.012 & 0.450 & 0.449 & 0.001 \\
$S_{2}$ & 0.130 & 0.136 & 0.043 & 0.430 & 0.435 & 0.012 & 0.300 & 0.299 & 0.002 \\
$S_{3}$ & 0.292 & 0.292 & 0.000 & 1.192 & 1.193 & 0.000 & 0.450 & 0.450 & 0.000 \\
$S_{4}$ & 0.906 & 0.893 & 0.014 & 1.506 & 1.191 & 0.010 & 0.600 & 0.597 & 0.001 \\
$S_{5}$ & 1.614 & 1.554 & 0.058 & 2.344 & 2.245 & 0.042 & 0.700 & 0.695 & 0.006 \\
$S_{6}$ & 0.114 & 0.142 & 0.078 & 0.144 & 0.443 & 0.002 & 0.300 & 0.300 & 0.000 \\
\hline
\end{tabular}


Sconario 4:

Results of scenario 3 indicate that this system can handle nnore products with higher arrival rates by increasing the number of servers. In this inproved design, product tvpes are increased to nine, and other pardmeters are the same as scenario 3. Table 7.6 shows results of scenario 4 .

Table 7.6. Results for scenario 1

\begin{tabular}{|c|c|c|c|c|c|c|c|c|c|}
\hline \multirow{2}{*}{  } & \multicolumn{3}{|c|}{$L_{q}$} & \multicolumn{3}{|c|}{$L$} & \multicolumn{3}{|c|}{ Utilization } \\
\hline & $\mathrm{MI}^{\prime} \Lambda$ & Simm & Diff & MPA & Sinnu & Diff & MI'A & Simul & Dill \\
\hline$S_{1}$ & 8.100 & 7.986 & 0.011 & 9.000 & 8.885 & 0.013 & 0.900 & 0.899 & 0.001 \\
\hline$S_{2}$ & 18.62 & 14.70 & 0.266 & 19.57 & 15.64 & 0.251 & 6) & 0.940 & 0010 \\
\hline$S_{3}$ & 0.233 & 0.228 & 0.020 & 1.133 & 1.125 & 0.007 & 0.450 & 0.448 & 0.003 \\
\hline$S_{4}$ & 8.150 & 8.614 & 0.054 & 9.050 & 9.513 & 0.049 & 0.900 & 0.899 & 0.001 \\
\hline$S_{5}$ & 8.150 & 9.011 & 0.095 & 9.050 & 9.915 & 0.087 & 0.900 & 0.904 & 0.004 \\
\hline$S_{6}$ & 8.150 & 7.392 & 0.102 & 9.050 & 8.283 & 0.093 & 0.900 & 0.890 & 0.001 \\
\hline
\end{tabular}

Scenario 5:

From the results of scenario 4 , it is casy to find that the imrival rates are too high, which leads to a high utilization of servers. The arrival rates of products (an be decreased to 0.4 transactions per minute, and then a reasonable utilization of all servers is found under this new system configuration. Tablo 7.7 shows resilts of scenario 5.

Table 7.7. Results for scenario 5

\begin{tabular}{|c|ccc|ccc|ccc|}
\hline$S^{3}$ & \multicolumn{3}{|c|}{$L_{q}$} & \multicolumn{3}{c|}{$L$} & \multicolumn{3}{c|}{ Utilization } \\
& MPA & Simu & Diff & MPA & Simu & Diff & MPA & Simu & Diff \\
\hline$S_{1}$ & 1.851 & 1.842 & 0.005 & 2.571 & 2.562 & 0.003 & 0.720 & 0.720 & 0.000 \\
$S_{2}$ & 2.482 & 2.403 & 0.033 & 3.242 & 3.162 & 0.026 & 0.760 & 0.757 & 0.003 \\
$S_{3}$ & 1.886 & 1.834 & 0.028 & 2.606 & 2.551 & 0.021 & 0.720 & 0.718 & 0.003 \\
$S_{1}$ & 1.863 & 1.840 & 0.013 & 2.583 & 2.560 & 0.009 & 0.720 & 0.720 & 0.000 \\
$S_{5}$ & 1.863 & 1.823 & 0.022 & 2.583 & 2.540 & 0.017 & 0.720 & 0.720 & 0.004 \\
$S_{6}$ & 1.863 & 1.889 & 0.011 & 2.583 & 2.612 & 0.011 & 0.720 & 0.723 & 0.004 \\
\hline
\end{tabular}

Scentario 6: 
Often, the external product arrival rates can not be controlled. In order to cxplore the optimal configuration of a system with higher arrival rates, this experiment increases the arrival rates of products and changes the number of servers. The arrival rates of products are set to 0.9 transactions por minute, which are relatively high compared to the initial design. Keeping the number of each type of server to two is an idcal configuration under this situation. Table 7.8 shows results of scenario 6.

Table 7.8. Results for scenario 6

\begin{tabular}{|c|ccc|cccc|ccc|}
\hline \multirow{3}{*}{$S$} & \multicolumn{3}{|c|}{$L_{q}$} & \multicolumn{3}{c|}{$L$} & \multicolumn{3}{c|}{ Utilization } \\
& MPA & Simu & Diff & MPA & Simu & Diff & NPA & Simu & Diff \\
\hline$S_{1}$ & 2.844 & 2.861 & 0.006 & 1.444 & 4.464 & 0.004 & 0.800 & 0.802 & 0.002 \\
$S_{2}$ & 4.351 & 4.364 & 0.003 & 6.041 & 6.057 & 0.003 & 0.815 & 0.846 & 0.001 \\
$S_{3}$ & 2.895 & 2.874 & 0.007 & 4.195 & 1.478 & 0.004 & 0.800 & 0.802 & 0.002 \\
$S_{4}$ & 3.109 & 2.971 & 0.046 & 4.729 & 4.592 & 0.030 & 0.810 & 0.810 & 0.000 \\
$S_{5}$ & 3.109 & 3.287 & 0.054 & 4.729 & 4.915 & 0.038 & 0.810 & 0.814 & 0.005 \\
$S_{6}$ & 2.438 & 2.460 & 0.009 & 4.000 & 4.025 & 0.007 & 0.780 & 0.783 & 0.0004 \\
\hline
\end{tabular}

Figures 7.1 to 7.6 present the comparison of quene longth and utilization between MPA and the simulation model.
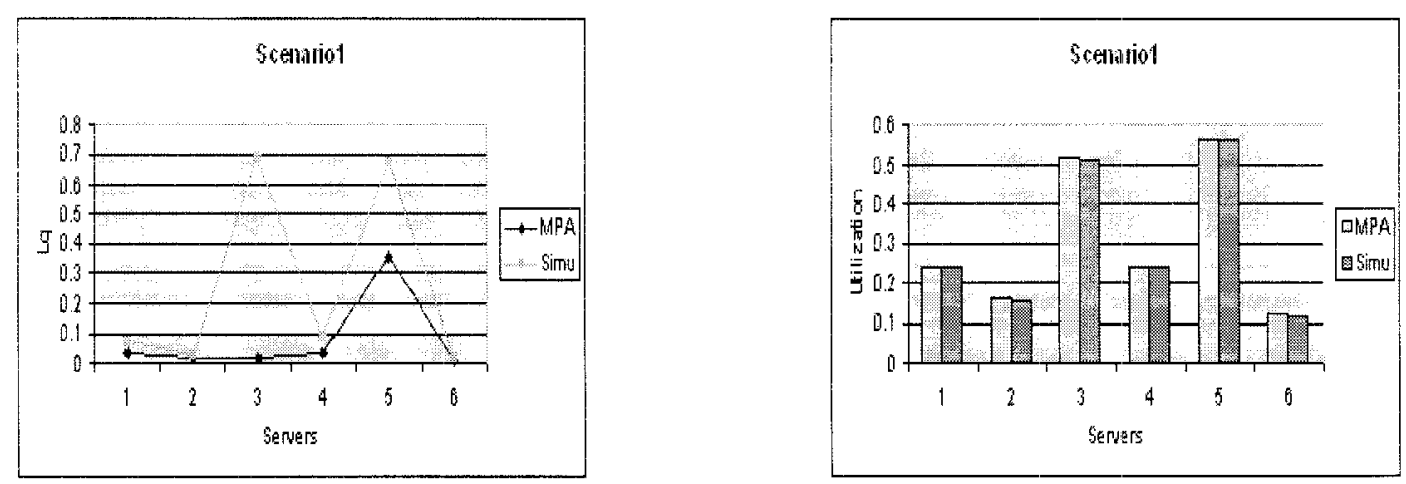

Figure 7.1. $L_{q}$ and utilization of servers in sconario 1

Experimental results indicate that the acouracy of MPA decreases when resonrco utilization is very low (og., less than 60\%) or very high (> 90\%). Because systom designers do not design systems in these utilization ranges, MPA is a very valuable tool in estinating system performance for normal ntilization ranges of $60-90 \%$. 



Figure 7.2. $L_{q}$ and ntilization of servers in scenario 2
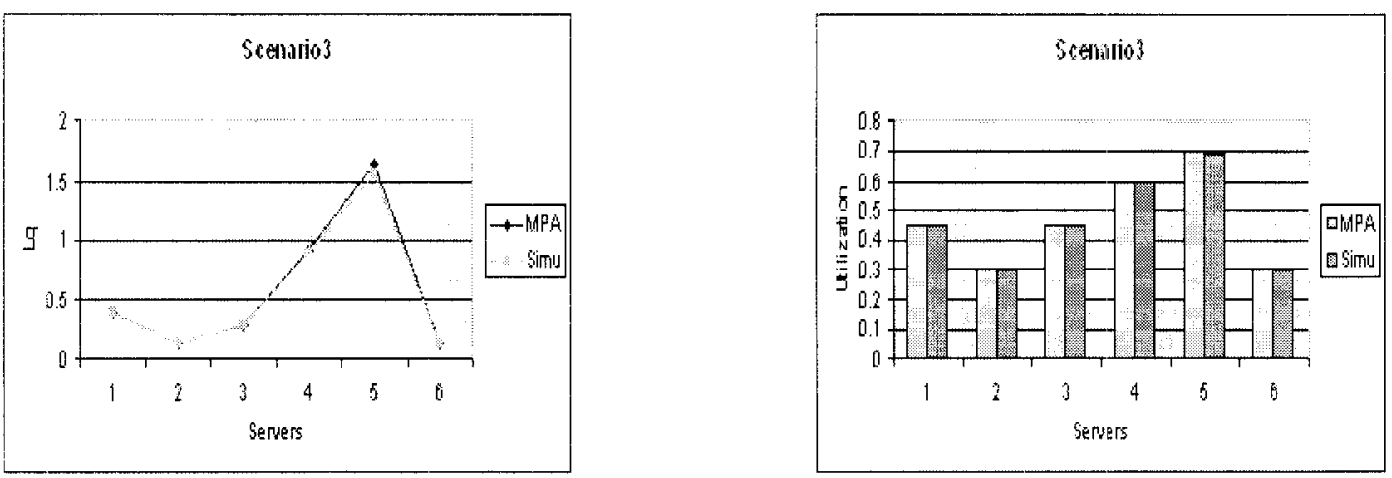

Figne 7.3. $L_{4}$ and utilization of servers in scenclio 3
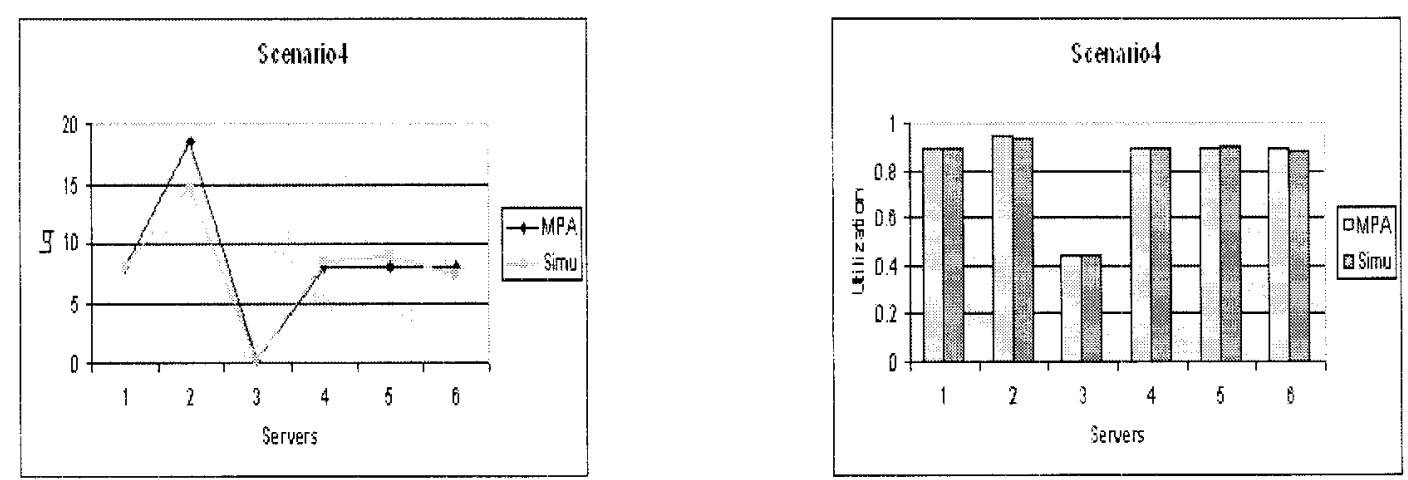

Figure 7.1. $L_{q}$ and utilization of servers in scenario 4

\subsection{Comparison between MPA and the conceptualization tools}

\subsubsection{Experimental design}

Malmborg [2002] presented a conceptualization tool for AVS/RS. This tool establishes an function of some key system attributes inchuding storage caparily, wack conliguration 

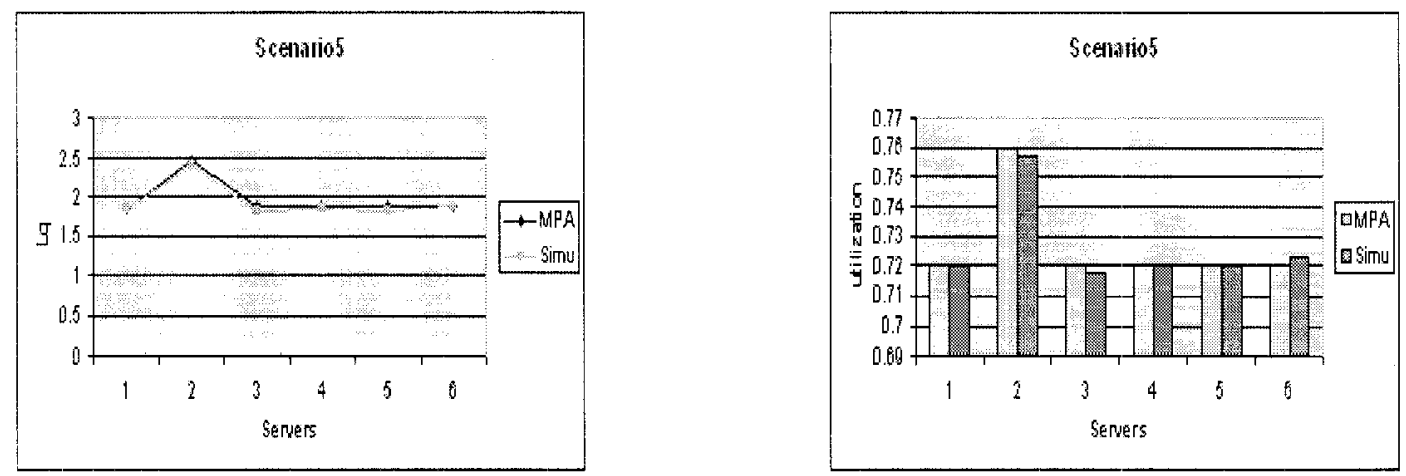

Figure 7.5. $L_{q}$ and utilization of servers in scenario 5
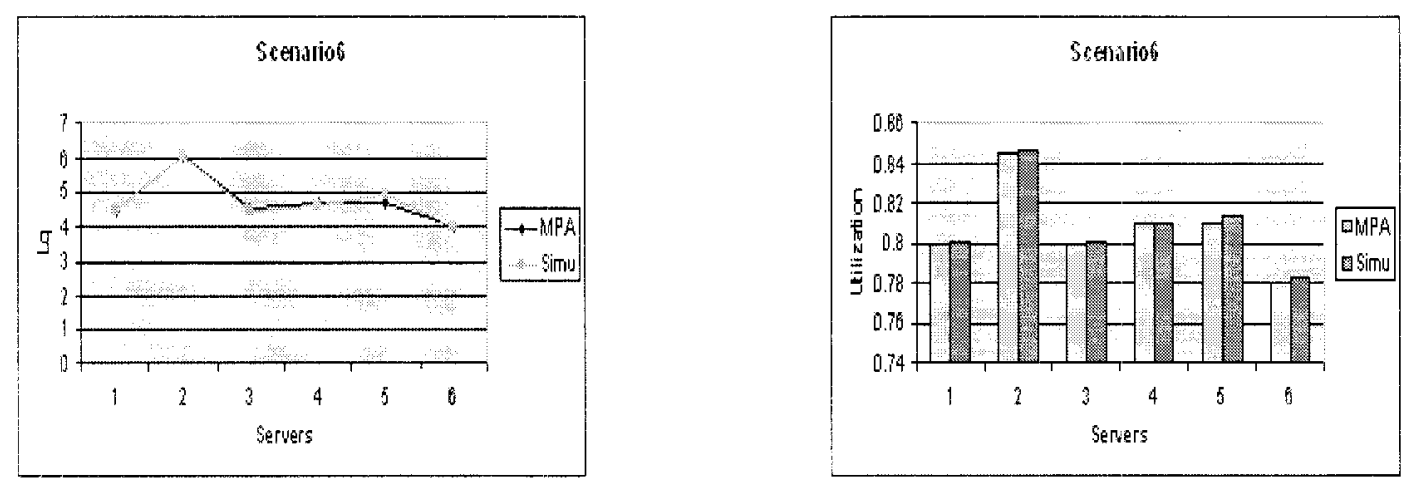

Figure 7.6. $L_{q}$ and utilization of servers in scenario 6

and flect size to estinate system performances. The default system configuration of this tool is tier-to-tice. It is valuable to make a comparison between this configuration and the tier-captive configuration by MPA.

Two kinds of comparison have been conducted. The first one is using the same set of input paraneters for MPA and the analytical unodel of Malmborg [2002] to make a comparison. Another comparison is based on a different line of thought: what designs under the two configurations would produce the same system performance.

As mentioned, the analytical model of Malmborg [2002] uses some system attributes such as rack configuration and flcet size to model the AVS/RS. However, MPA uses process times to establish the model of AVS/RS. Before the comparison, 
the connection between these two tools noeds to be established. Table 7.9 lists all input parameters of the analytical model of Malmborg [200(2].

Table 7.9. Parameters of the amalytical model of Malmborg [2002]

\begin{tabular}{|c|c|}
\hline Parameters & Mcaning \\
\hline$\lambda_{s}$ & Arrival rate of storage request with unit of minute \\
\hline$\lambda_{R}$ & Arrival rate of retrieval request with unit of minute \\
\hline$T$ & Total number of tiers of the warehouse rack \\
\hline$A$ & Total number of aisles of the warehouse rack \\
\hline$V$ & Total number of vehicles \\
\hline$L$ & Total number of lifts \\
\hline$n$ & Total space requirement \\
\hline$C$ & Total number of rack columms \\
\hline$u_{h}$ & The height per unit cell of the rack \\
\hline$u_{d}$ & The depth per unit cell of the rack \\
\hline$u_{n !}$ & The width per unit coll of the rack \\
\hline$u_{n}$ & The width per aisle \\
\hline$V_{u}$ & Velicle horizontal speed \\
\hline$V_{l}$ & Veliclo/lift vertical speed \\
\hline Cost_V & Cost per vehicle with unit of $\$ 1000$ \\
\hline Cost_L & Cost per lift with unit of $\$ 1000$ \\
\hline Cost_Cell & Cost per rack cell with unit of $\$ 1000$ \\
\hline
\end{tabular}

The warchouse size can be calculated as follows:

- Total width of the warchouse

$$
u_{w} \cdot C=u_{w} \cdot \frac{w}{2 \cdot T \cdot A}
$$

- Total height of the warchouse

$$
u_{h} \cdot T
$$

- Total deptle of the warchouse

$$
\left(2 \cdot u_{i l}+u_{i l}\right) \cdot(A-1)
$$


The lift process time for the thin tier can be calculated as:

$$
t_{0}=\frac{(t-1) \cdot u_{h}}{V_{l}}
$$

The volicle process time can be estimatcd as:

$$
t_{0}=\frac{3 \cdot u_{w} \cdot C+\left(2 \cdot u_{d}+u_{u}\right) \cdot(A-1)}{V_{u}}
$$

The storage time in storage area is:

$$
t_{o}=\frac{1}{\lambda_{r}}
$$

\subsubsection{Experimental results and discussion}

A study case has been designed to make the comparison. The input paraneters are listed in Tables 7.10 and 7.11.

Table 7.10. Input parameters for the analytical model of Malmborg [2002]

\begin{tabular}{|c|c|}
\hline Parameter & Valuc \\
\hline$\lambda_{s}$ & 0.5 \\
\hline$\lambda_{r}$ & 0.5 \\
\hline$T$ & 4 \\
\hline$A$ & 10 \\
\hline$V$ & 3 \\
\hline$L$ & 2 \\
\hline$C$ & 125 \\
\hline$u_{h}$ & 6 \\
\hline$u_{l}$ & 1.5 \\
\hline$u_{u}$ & 5 \\
\hline$u_{a}$ & 2 \\
\hline$V_{u}$ & 100 \\
\hline$V_{l}$ & 200 \\
\hline
\end{tabular}

In the tier-to-tier configuration, four vehicles can visit any tier. Malmborg $[2002]$ andytical model can be used to model this system configuration. However, in the tier-captive configuration, every vehicle can travel only on one tier. This system 
Table 7.11. Equivalent input parameters for MPA

\begin{tabular}{|c|c|}
\hline Paraneter & Value \\
\hline$\lambda_{p}$ & 0.5 \\
\hline$t_{o}$ (Lift tier 1$)$ & 0.01 \\
\hline$t_{o}$ (Lift tier 2$)$ & 0.06 \\
\hline$t_{o}$ (Lift tier 3$)$ & 0.12 \\
\hline$t_{0}$ (Lift tier 4$)$ & 0.18 \\
\hline$t_{o}$ (Vehicle) & 0.9 \\
\hline$t_{o}$ (Storage area) & 2 \\
\hline
\end{tabular}

configuration is modeled by MPA. This difference of system configuration leads to different utilization. Four different inputs and outputs under two system configurations are presented in Table 7.12 .

Table 7.12. Comparison of outputs

\begin{tabular}{|c|c|c|c|c|c|}
\hline Tool & Utilization & $\begin{array}{c}\mathrm{L}=1 \\
\mathrm{~V}=4\end{array}$ & $\begin{array}{c}\mathrm{L}=1 \\
\mathrm{~V}=8\end{array}$ & $\begin{array}{l}\mathrm{L}=2 \\
\mathrm{~V}=4\end{array}$ & $\begin{array}{l}\mathrm{L}=2 \\
\mathrm{~V}=8\end{array}$ \\
\hline \multirow{2}{*}{ Conceptualization tools } & $U_{l}$ & 0.64 & 0.61 & 0.33 & 0.33 \\
& $U_{v}$ & 0.81 & 0.19 & 0.51 & 0.27 \\
\hline \multirow{2}{*}{ MPA } & $U_{l}$ & 0.37 & 0.37 & 0.19 & 0.185 \\
& $U_{v}$ & 0.90 & 0.45 & 0.90 & 0.15 \\
\hline
\end{tabular}

From experimental results shown in Table 7.12, one common feature of ticr-totiel: and tiex-captive system configurations can be seen. The utilization of lifts is dependent upon the vehicle utilization and other system attributes when vehicles performance is maintained to be the same. The utilization of lifts depends on the lift performance such as the speed, and other factors including fleet size, arrival rates of $S / R$ requests.

The difference in the utilization of vehicles is listed in Table 7.12. The utilization of vehicles depends on the utilization of lifts in the tier-to-tier system.

The opposite experiment is to dotermine what designs under two configurations lead to the same system performance. Table 7.13 presents the experimental results. 
Table 7.13. Comparison of inputs

\begin{tabular}{|c|c|c|c|}
\hline & MPA & Conceptualization tools & Conceptualization tools \\
\hline L & 1 & 2 & 3 \\
\hline $\mathrm{V}$ & 8 & 5 & 4 \\
\hline$U_{l}$ & 0.37 & 0.33 & 0.33 \\
\hline$U_{n}$ & 0.45 & 0.41 & 0.47 \\
\hline
\end{tabular}

From Table 7.13, tier-to-ticr AVS/RS uses more lifts to achieve the samo utilization as tiel-captive AVS/RS. This suggests that tier-captive AVS/RS can utilize lifts better. On the other hand, tier-captive AVS/RS needs more vehicles to achicvo the sane system perfornance as the tier-to-tier AVS/RS. One possible reason is vehicles an only travel on designed ticrs, which may increase the idle time of vehicles. This is a potential disadvantage of tier-captive AVS/RS. 


\section{CHAPTER 8}

\section{CONCLUSION}

AVS/RS, as a relatively new antonomons warehouse $S / R$ tedmology is presented in this thesis. Two configurations of AVS/RS are possible: ticr-to-tier and tierapptive. The configuration with tier captive vehicles is studied in this thesis. It is compared with the traditional canc-based AS/RS technology, and some advantages of AVS/RS are presented. There are many ways to analyze the AVS/RS. Wo used the OQN method. MPA, a tool for evaluating OQNs, was chosen to estimate performance moasures of AVS/RS. Several scenarios wore designed to verify the accuracy of MPA in evaluating AVS/RS. Comparison with a simulation model shows that MPA is axtequate to model the AVS/RS when utilization is between 60 and 85 pereent. However, the AVS/RS with tier-to-tior vehicles is not suitable to nse OQN to analyze system performance, which may be solved by another type of quening network, SOQN. There is a broad scope for improvement in this area. The comparison betwen MPA and another performance analyzer of AVS/RS, indicates the common and different features of tier-captive and tick-to-tier AVS/RS. 


\section{REFERENCES}

J. Ashayeri, R. Hents, M.W.T.Valkonburg, H. Veraart, and M. Wilhelm. A geonetrical approach to computing expected cycle times for zone-based storage layouts in ass/ris. Int. J. Prod. Res., 10):4467 1483, 2002.

A. Benamas, Z. Sari, and N. Ghouali. Performance analysis for multi-aisle antomated storage/retrieval systems using visual petri net developer. In Proceedings 2003 IEEE International Symposium on Computatioal Intelligence in Robotics and. Automation, 2003.

J. Berg and A. Gademann. Simmlation study of an antomated stomage/retrieval system. Int.J.prod.res., 38:1339 1356, 2000.

Y. Bozer and J. White. Travel time models for antomated stroage/retrieval systems. IIE Transactions, 16:329-338, 1981.

J. Cannoron. Using visual basic to control Promodel, 1999.

W. Choi and H. Shin. A real-time sequence control system for the level production of the antonnoloile assembly line. Computers ind. Engng, 33:769 772, 1997.

M. Dotoli and M. Fanti. Deadlock detection and avoidance strategios for antomated storage and retrieval systems. IEEE Transactions on systems, man and cybernetics, $37: 541 \cdot 552,2007$.

M. Dotoli and M. P. Fanti. A colourd petri net models for antomated stomage and retrieval systems serviced by rail-guded vehicles: a control perspective. Int. I. Computer Integrated Mamufacturing, 18:122 136,2005. 
M. Dotoli, M. Fanti, and G. Iacobellis. Comparing deadlock detection and avoidance policies in automated storage and retrieval systems. In 2004 IEEE International Conference on Systems, Man and Cybernetics, 2004.

P. Egbelu. Franework for dymanic positioning of storage/retrieval machines in an automated storagc/retrieval system. Int. J. Prod. Res., 29:17 37, 1991.

P. Egbelu and C. Wu. A comparison of dwell point rules in an antonated storage/rotricval system. Int. .J. Prod. Res.. 31:2515 2530, 1993.

M. Fanti, B. Maione, and B. Turchiano, Event-based feedback control for dearlock avoidance in flexible production systems. IEEE Transactions on robotics and antomation, 13:317-363, 1997.

M. P. Fanti. Event-based controller to avoid deadlock and collisons in zone-control agvs. Int.J.prod.res., 10:1453-1478, 2002.

M. Fuknuari, K. P. Bennet, and C. J. Malmborg. Decision-trec learning in dwell point policies in antononous vehicle storage and retrieval systems (avsrs). In 2004 International Conference on Machine Learning and Applications, ICMLA '04, 2004.

S. Graves, W. Hausman, and L. Schwarz. Stomge-retrieval interleaving in automatic Warchonsing systems. Management Science, 23:935-946, 1977.

W. Hausman. L. Schwarz, and S. Graves. Optimal storage assigninent in automatic Warehousing systems. Management Scrence, 22:629 638, 1976.

Y. Hu, S. Huang, C. Chen, W. Hsu, A. Toh, C. Loh, and T. Song. Travel time analysis of a new antomated storage and retricval system. Computers 83 Operations Research. 32:1515 1544, 2005.

H. Hwang and C. KO. A study on multi-aisle system served by a single storage/retrieval machine. Int. J. Prod. Res., 26:1727 1737, 1988. 
H. Hwang and J. Lim. Deriving an optimal dwell point of the storage/retrieval machine in an antomated storage/retrieval systenn. Int. J. Prod. Res. 31:2591 $2602,1993$.

R. Inman. Asrs sizing for recrating automative assembly sequences. Int. J.prod.res. $41: 847-863,2003$

P. Kueln. Approximate analysis of general queneing network by decomposition. IEEE Tiansactions on communications, 27:113-126, 1979.

S. Lee, R. Souza, and E. Ong. Simulation modelling of a namow aisle antomated sitorage and rotrieval system (as/rs) serviced by rail-guided veliches. Computers in Industry, 30:211--253, 1996.

S. Lin and H. Wang. Modeling an antonated storage and retrieval system using petri nets. Int.J.prod.res., 33:237-260, 1995.

J. Macro and R. Sahni. A simulation tool to determine warchouse efficiencies and storage allocations. In Winter Simulation Conference, 2002.

C. Malmborg and K. Altassan. Analysis of storage assignment policics in less than unit load warchousing systems. Int. J. Prod. Res., 36:3459-3475, 1998.

C. J. Malunborg. Conceptualizing tools for autonomous vehicle storage and retrieval systcms. Int. J. Prod. Res., 10:1807 1822, 2002.

M. Mansuri. Cycle-time computation, and dedicatated storage assignment, for ass 1 systenis. Computers ind. Engng., 33:307 310, 1997.

G. Meng and S. Heragn. Batch size nodeling in a multi-item, discrete manufacturing system via an open qucueing notwork. IIE Transactions, 36:743 753, 2004.

G. Meng, S. IIcragu, ancl II. Zijun. Reconfigurable layout problem. Int. J. Prod. Res., 12:1709 1729, 2004 .

B. Park. An optimal dwell point policy for antomated storage/retrieval systems with nniformly distributed, rectangular racks, Int. J. Prod. Res., 39:1169-1180, 2001. 
B. Petcrs, J. Smith, and T. Hale. Closed form models for deterning the optimal dwell point location in automated storage and retrieval systems. Int. J. Prod. Res., 34: $1757 \quad 1771,1996$.

I. Potre, T. Lerher, J. Kranberger, and M. Sranl. Simulation model of multi-shuttle antomated storage and retrieval systems. Journal of Materials Processing Technolog:y, 157-158:236-244, 2004

M. Rosenblatti and Y. Roll. Warehouse design with storage policy considerations. Int.J.prod.res., 22:809--821, 1981.

M. Rosenblatt and Y. Roll. Warchouse capacity in a stodlastic cuviromnent. Int.J.prod.res., 26:1817-1851, 1988.

7. Sari, S. Grasman, and N. Ghonali. Inpact of pickup/delivery stations and restoring conveyor locations on retrieval time models of flow-back automated storage and retricval systems. Production Planning \& Control, 18:105-116, 2007.

M. Srinivasan and S. Heragu. Analysis of manufacturing systems via semi-opns. 2007.

U. Wen, D. Chang, and S. Chen. The impact of acceleration/deceleration on traveltime nodcls in class-based automated s/r systems. IIE Transactions, 33:599 608 . 2001.

W. Whitt. The queucing network analyzer. The Bell System Technical Journal, 62: $2779-2815,1983$. 


\section{CURRICULUM VITAE}

\section{Xiao Cai}

Department of Industrial Engineering

Speed School of Engineering, University of Louisville

Louisville, $\mathrm{KY} 10292$

Phone:(502)296-7789

\section{Education}

\section{B.S., Control Science and Technology}

Huarlong University of Science and Technology

$2001-2005$

M.S., Industrial Engineering

University of Louisville

$2006-$ present

\section{Awards \& Honors}

Graduate Research fellowship

LoDI (The Logistics and Distribution Institute)

Cinversity of Louisville

August 2007 - present. 
Travel Award for the INFORMS Annual Meeting

Department of Industrial Engincering

University of Louisville

November 7 - 20, Seattle, Washington (2007).

Travel Award for the INFORMS Midwest Region Meeting

Department of Industrial Engincering

University of Louisville

August 24 - 25, Evanston, Illinois (2007).

Graduate Research scholarship

Departinent of Industrial Engineering

University of Lonisville

August $20006-$ July 2007.

First Prize Scholarship Award

Department of Control Science and Tednuology

Intazhong University of Science and Technology, China

$20(01-2005$.

\section{Professional Membership}

Student Chapter of INFORMS at University of Louisville

Welmaster, $2006-2007$

President, 2007-present

\section{Professional Experiences}




\section{Research Fellow}

LoDI, University of Louisville,

Angust 2007 - present

\section{Graduate Research Assistant}

Industrial Engincering; University of Louisville,

August 2006 - August 2007

\section{Research Assistant}

System Enginering, Lab), Huahoug University of Science and Tedmology Aigust 2005 - July 2007

\section{Presentations}

"Web interface for conceptualization AS/RS and AVS/RS tools"

Cai, X., Heragn, S.S, Krishuanmerthy, A. and Mahnborg, C.J., Vevember 7 - 20, Seatitle, Waslington (2007). 